\title{
Construction of reporter gene assays using CWP and PDR mutant yeasts for enhanced detection of various sex steroids
}

\author{
Sayoko Ito-Harashima', Mami Matano ${ }^{1}$, Kana Onishi', Tomofumi Nomura', Saki Nakajima', Shingo Ebata',
} Kazuhiro Shiizaki ${ }^{1,2}$, Masanobu Kawanishi ${ }^{1}$ and Takashi Yagi ${ }^{{ }^{*}}$

\begin{abstract}
Background: Sex steroid hormone receptors are classified into three classes of receptors: estrogen receptors (ER) a and $\beta$, androgen receptor (AR), and progesterone receptor (PR). They belong to the nuclear receptor superfamily and activate their downstream genes in a ligand-dependent manner. Since sex steroid hormones are involved in a wide variety of physiological processes and cancer development, synthetic chemical substances that exhibit sex steroid hormone activities have been applied as pharmaceuticals and consumed in large amounts worldwide. They are potentially hazardous contaminants as endocrine disruptors in the environment because they may induce inappropriate gene expression mediated by sex steroid hormone receptors in vivo.

Results: To develop simple reporter gene assays with enhanced sensitivity for the detection of sex steroid hormones, we newly established mutant yeast strains lacking the CWP and PDR genes encoding cell wall mannoproteins and plasma membrane drug efflux pumps, respectively, and expressing human ERa, ER $\beta, A R$, and PR. Reporter gene assays with mutant yeast strains responded to endogenous and synthetic ligands more strongly than those with wild-type strains. Sex steroid hormone activities in some pharmaceutical oral tablets and human urine were also detectable in these yeast assays.

Conclusions: Yeast reporter gene assay systems for all six steroid hormone receptors, including previously established glucocorticoid receptor (GR) and mineralocorticoid receptor (MR) assay yeasts, are now available. Environmental endocrine disrupters with steroid hormone activity will be qualitatively detectable by simple and easy procedures. The yeast-based reporter gene assay will be valuable as a primary screening tool to detect and evaluate steroid hormone activities in various test samples. Our assay system will strongly support the detection of agonists, antagonists, and inverse agonists of steroid hormone receptors in the field of novel drug discovery and assessments of environmental pollutants.
\end{abstract}

Keywords: Estrogen receptor, Androgen receptor, Progesterone receptor, Steroid hormone, Saccharomyces cerevisiae, Reporter gene assay, Agonist, Antagonist, Inverse agonist

\footnotetext{
* Correspondence: yagi-t@riast.osakafu-u.ac.jp

'Department of Biological Sciences, Graduate School of Science, Osaka Prefecture University, 1-2 Gakuen-cho, Naka-ku, Sakai, Osaka 599-8570, Japan Full list of author information is available at the end of the article
} 


\section{Introduction}

The sex steroid hormones, estrogens, androgens, and progesterone, play essential roles in sexual differentiation, reproduction, and many other physiological processes by regulating gene expression in vertebrates [1-4]. The receptors of these steroids, estrogen receptors $\alpha$ and $\beta$ (ER $\alpha$ and $\operatorname{ER} \beta$ ), androgen receptor (AR), and progesterone receptor (PR), belong to the nuclear receptor (NR) superfamily, which also includes receptors for corticosteroids, vitamin $\mathrm{D}_{3}$, thyroid hormones, and retinoic acids [5]. They are ligand-dependent transcription factors with three characteristic domains that are structurally similar: a transcription activation domain (AD), DNA-binding domain (DBD), and ligand-binding domain (LBD) located from the $\mathrm{N}$ to $\mathrm{C}$ terminus. Ligand-bound receptors translocate from the cytosol into the nucleus, at which they bind as their homodimers to specific DNA sequences (cis-element) called estrogen response elements (EREs) for estrogen receptors [6, 7] and glucocorticoid response elements (GREs) for AR and PR $[8,9]$. Following the recruitment of co-regulators that activate or repress NR-dependent transcription, sex steroid hormone receptor complexes temporally and spatially regulate the transcription of target genes on the genome [10-12].

Sex steroid hormones are synthesized not only in the gonads, but also in the adrenal glands and brain. By influencing the reproductive tract, sexual phenotype, and secondary sexual characteristics of male and female animals including humans, sex steroid hormones entirely control the reproductive process: sexual development and maturation, sex-dependent brain differentiation, and sexual behavior [3, 13-15]. These steroids affect other tissues in non-reproductive systems that are not traditionally regarded as targets. For example, estrogens exert protective effects against osteoporosis, neurodegenerative diseases, cardiovascular disease, and obesity $[16,17]$. Sex steroid hormones are also involved in the development of cancers, such as breast, ovarian, and endometrial cancers in females and prostate cancer in males [18]. Therefore, these sex steroids are considered to be important clinical tools in diagnostic and prognostic research, and synthetic chemicals with the ligand activities of sex steroid receptors have been developed for therapeutic approaches [19-22].

Natural and synthetic steroid hormones, including sex steroids, excreted into the environment have recently been identified as a serious public health threat due to their adverse effects on humans and wild life [23-25]. Simple reporter gene assay systems based on mammalian cells and budding yeasts have been developed to detect environmental steroid contaminants [26-31]. We and other researchers reported that various chemical substances, including corticosteroids, were detectable at greater sensitivity in yeast strains in which genes encoding the cell wall mannoproteins CWP1 and CWP2 and/or plasma membrane-localized ATP-binding cassette $(A B C)$ transporters $P D R 5$ and $P D R 10$ were deleted than in wild-type yeast strains $[28,32-35]\}$. The sensitivities of yeast-based reporter gene assay systems are generally less than those of mammalian cell-based assay systems $[26,31]$. In yeasts, the cell wall provides a strong physical barrier to restrict the permeability of chemical substances into cells. Cwp1p and Cwp2p, major mannoproteins, are localized in the external cell wall layer and important for maintaining a rigid wall structure in yeasts [36-38]. In addition, pleiotropic drug resistance (PDR) mediated by plasma membrane-localized ABC transporters, which constitute active drug efflux pumps, functions as a dynamic biochemical xenobiotic defense system in yeasts. Various unrelated chemicals with a broad spectrum are pumped into the extracellular space in order to minimize their toxic effects. Intracellular chemical concentrations are considered to be elevated due to enhanced permeability and/or the inhibition of the extracellular efflux of substances in mutants.

In the present study, we constructed yeast strains that lacked the cell wall mannoproteins Cwp1p/Cwp2p and/ or plasma membrane efflux pumps Pdr5p/Pdr10p and expressed the human sex steroid hormone receptors, $\mathrm{ER} \alpha, \mathrm{ER} \beta, \mathrm{AR}$, and $\mathrm{PR}$, to establish highly sensitive reporter gene assays. The ligand-specific responses of these newly established reporter gene assay strains were compared with those of wild-type assay strains using natural and synthetic ligands, pharmaceuticals, and human urine.

\section{Materials and methods}

\section{Strains and media}

The Escherichia coli strain, DH5 $\alpha$, was used as a host strain to amplify plasmid DNA. Saccharomyces cerevisiae strains are listed in Table S-1. All S. cerevisiae strains used in the present study were isogenic with W303a (MATa, ura3-1, ade2-1, trp1-1, leu2-3, his3-11, 15, can1-100). Yeast extract peptone dextrose (YPD) and synthetic dextrose complete dropout (SDC-X) media were prepared as previously described [39]. YEP(Gal) and synthetic galactose complete dropout (SGC-X) media contained $1 \%$ or $2 \%(\mathrm{w} / \mathrm{v})$ galactose instead of dextrose.

\section{Chemicals}

Testosterone (TS; purity: $\geq 97 \%$ ), $5 \alpha$-dihydrotestosterone (DHT; $\geq 95 \%)$, trenbolone acetate (TBA; $\geq 98 \%$ ), zeranol (Zer; $\geq 99 \%$ ), medroxyprogesterone 17-acetate (MPA; $\geq 98 \%$ ), corticosterone (CS; $\geq 95 \%$ ), and hydrocortisone (HC; $\geq 97 \%$ ) were purchased from Wako Pure Chemical Industries, Ltd. (Osaka, Japan). Dimethyl sulfoxide (DMSO), dithiothreitol (DTT), 17 $\beta$-estradiol (E2; $\geq 97 \%$ ), 
and progesterone (PS; $\geq 97 \%$ ) were obtained from Nacalai Tesque (Kyoto, Japan). Diethylstilbestrol (DES; $\geq 99 \%$ ), aldosterone (AS; $\geq 95 \%$ ), estrone (E1; $\geq 99 \%)$, estriol (E3; $\geq 99 \%$ ), tamoxifen (Tam; $\geq 99 \%$ ), 17 $\beta$-hydroxy-17-methylandrosta-1,4-dien-3-one (17 $\beta$ - $\mathrm{H}$; $\geq 98 \%)$, flutamide (Flu; $\geq 99 \%$ ), $17 \alpha$-methyltestosterone (17 $\alpha$-MTS; $\geq 98 \%$ ), mifepristone (Mif; $\geq 98 \%$ ), spironolactone (Spi; $\geq 97 \%$ ), stanozolol (STA; $\geq 98 \%$ ), 19-norethindrone (NET; $\geq 98 \%$ ), desogestrel (DSG; $\geq 98 \%$ ), drospirenone (DRSP; $\geq 98 \%$ ), methyl-piperidino-pyrazoledihydrochloride hydrate (MPP; $\geq 97 \%$ ), and $o$-nitrophenyl- $\beta$-D-galactopyranoside (ONPG) were purchased from Sigma Aldrich Chemical Co. (St. Louis, MO, USA). Ethinyl estradiol (EE2; $\geq 98 \%$ ) was purchased from Cayman Chemical Company (Ann Arbor, MI, USA). 17 $\alpha$-Methylandrostan-17 $\beta$-ol-3-one (17 $\alpha$-MAS; $293 \%)$ was obtained from Tokyo Chemical Industry Co., Ltd. (Tokyo, Japan). Raloxifen hydrochloride (Ral; $\geq 98 \%$ ) and levonorgestrel (LNG; $\geq 98 \%$ ), were purchased from LKT Laboratories, Inc. (St. Paul, MN, USA). ICI 182, 780 (ICI; $\geq 99 \%$ ), diarylpropionitrile (DPN; $\geq 99 \%$ ), and propyl pyrazole triol (PPT; $\geq 99 \%$ ) were purchased from Tocris Bioscience (Bristol, UK). Dienogest (DNG; 98\%) and gestodene (GTD; 98\%) were supplied from Toronto Research Chemicals Inc. (North York, ON, Canada). Restriction enzymes, DNA modification enzymes, and other chemicals were obtained from Wako Pure Chemical Industries, Ltd., TaKaRa Bio Inc. (Otsu, Japan), or TOYOBO Co. (Osaka, Japan).

\section{Plasmid construction}

AR and PR expression plasmids were constructed for the development of AR and PR ligand reporter gene assays. The primer sequences used in the present study were synthesized by Sigma-Aldrich Japan (Tokyo, Japan) and are listed in Table S-2.

DNA fragments containing human AR complementary DNA (cDNA) (DDBJ/EMBL/GenBank accession number M23263) were obtained by a polymerase chain reaction (PCR) from the plasmid pcDNA3.1-AR [40], with the primers ARfRbBm and ARrXh, which contain a restriction site and/or yeast ribosomal-binding consensus sequence near the initiation codon. PCR was performed with high-fidelity PCR polymerase KOD plus (TOYOBO Co., Ltd.), according to the manufacturer's instructions. The amplified fragment of approximately $2.8 \mathrm{~kb}$ was digested with BamHI and XhoI, and cloned into the BamHI-SalI sites of the expression vector pUdp6 [41]. The resultant plasmid was designated as pUdp6AR. Plasmids were isolated and purified using the QIAGEN Mini Prep Kit (Valencia, CA, USA).

Human PR cDNA (NM_00926) was amplified from human uterus total RNA (TaKaRa Bio Inc.) by reversetranscription PCR (RT-PCR). cDNA was obtained using SuperScript III reverse transcriptase (Invitrogen,
Carlsbad, CA, USA). Three overlapping DNA fragments containing PR ORF were amplified by PCR using the KOD-plus PCR kit with three sets of primers, hPR1f and hPR948r, hPR801f and hPR1887r, and hPR1745f and hPR2876r, respectively. Using the three amplified DNA fragments of $1 \mathrm{~kb}$ each as templates, fusion PCR was performed with the primers hPRfBg and hPRrXh. The amplified fragment of approximately $2.9 \mathrm{~kb}$ was digested with $B g l \mathrm{II}$ and XhoI, and ligated to the BamHI and SalI sites of pUdp6 to construct pUdp6PR. The plasmids were isolated and purified using the QIAGEN Mini Prep kit. The nucleotide sequences of $A R$ and PR ORFs were confirmed using the ABI DNA sequencer (Applied Biosystems, CA, USA).

\section{Construction of $E R a, E R \beta, A R$, and PR reporter gene assay yeasts}

Yeast transformation was performed using the lithium acetate procedure as previously described [42]. ER $\alpha$ and ER $\beta$ assay yeasts established in wild-type W303a were previously reported [27]. To construct ER $\alpha$ and ER $\beta$ assay yeasts in mutant strains (see Table S-1) [28], the reporter plasmid pTERE-3z carrying three copies of the ERE: AGGTCAACATGACCT (the half site of ERE is underlined) and the expression plasmid for the human transcriptional coactivator SRC1-e, pESC-Leu-SRC1e [27] were introduced in each mutant strain. A transformant from each strain grown on SDC-TRP/LEU agar medium was isolated and used as a host for subsequent transformation. The ER $\alpha$ expression plasmid 2MpUC6ER $\alpha$ and ER $\beta$ expression plasmid pUCura3ER $\beta$ [27] were linearized by EcoRV and NcoI, respectively, and integrated into the ura3 locus in the yeast genome by homologous recombination. To construct the AR and PR assay yeasts, the reporter plasmid pYT $\beta$-GRE-R8CS carrying eight copies of the GRE: AGAACAAACTGTTCT [28] and pESC-Leu-SRC1e were introduced into wildtype W303a and mutant strains (Table S-1). The AR expression plasmid pUdp6AR and PR expression plasmid pUdp6PR were linearized by EcoRV digestion and introduced into transformants with pYT $\beta$-GRE-R8CS and pESC-Leu-SRC1e. Transformants carrying three plasmids, a reporter plasmid, SRC-1e expression plasmid, and NR expression plasmid, were selected on SCD-TRP/ LEU/URA agar plates. NRs and SRC-1e were under the control of the GAL1, 10 dual directional promoter, and their expression was induced by galactose in media. To construct control strains for the antagonist and inverse agonist assays, the plasmids pESC-LEU-CYCp [28] and YCplac 22 (TRP1, CEN4-ARS1) [43] were introduced into the W303a, YSA172 (cwp1 $\Delta p d r 5 \Delta)$, YSA173 $(c w p 1 \Delta c w p 2 \Delta)$, and YSA354 (pdr5 $\Delta p d r 10 \Delta)$ strains (Table S-1), respectively, and EcoRV-linearized pUdp6 was subsequently integrated at the ura3-1 locus by 
homologous recombination, as described above. Transformants were selected on SDC-TRP/LEU/URA agar plates. The resultant transformants were designated as CYC W303a, CYC cwp $1 \Delta p d r 5 \Delta$, CYC $c w p 1 \Delta c w p 2 \Delta$, and CYC pdr5 $\Delta p d r 10 \Delta$, respectively.

\section{Sex hormone activity assay using $E R a, E R \beta, A R$, and PR reporter yeasts}

The assays for AR and PR were conducted as described previously [28]. Briefly, the yeast strains were pregrown overnight at $30{ }^{\circ} \mathrm{C}$ in SDC-TRP/LEU/URA medium containing $2 \%$ glucose, and the optical density (OD) at 595 $\mathrm{nm}$ of each culture was adjusted to 1.0 with the same medium. A 1- $\mu$ l aliquot of the test chemicals dissolved in DMSO, $10 \mu \mathrm{l}$ of the overnight culture yeast, and $90 \mu \mathrm{l}$ of SGC-TRP/LEU/URA containing $2 \%$ galactose were mixed in a 96-well polystyrene microplate with subsequent incubation for $18 \mathrm{~h}$ at $30{ }^{\circ} \mathrm{C}$ (glucose:galactose $=$ $0.2 \%: 1.8 \%)$. In the assays for ER $\alpha$ and ER $\beta$, SDC-TRP/ LEU/URA/PHE/TYR medium containing $2 \%$ glucose was used for the preculture. Ten-microliter aliquots of the yeast suspension (adjusted $\mathrm{OD}_{595}$ to 1.0) were mixed with $1 \mu \mathrm{l}$ of the test chemical and $90 \mu \mathrm{l}$ of SGC-TRP/ LEU/URA/PHE/TYR containing $1 \%$ galactose instead of $2 \%$ galactose to induce the expression of ERs and SRC$1 \mathrm{e}$ in ligand exposure (glucose:galactose $=0.2 \%: 0.9 \%$ ). When the agonistic activities of EE2, DES, DPN, and PPT were examined, each yeast culture pregrown in SDC-TRP/LEU/URA/PHE/TYR medium containing 2\% glucose was resuspended in synthetic dropout medium (-TRP/LEU/URA/PHE/TYR) containing $1.2 \%$ glucose and $0.8 \%$ galactose in order to reduce ligandindependent lac $Z$ expression. $\mathrm{OD}_{595}$ of the suspension was adjusted to 0.1 with the same medium. One microliter of the test chemical was mixed with $100 \mu \mathrm{l}$ of the yeast cell suspension in 96-well microtiter plates, which were then incubated at $30^{\circ} \mathrm{C}$ for $18 \mathrm{~h}$.

Each cell suspension $(5 \mu \mathrm{l}$ for ER $\alpha$ and ER $\beta$, and $10 \mu \mathrm{l}$ for $A R$ and PR) was transferred to a new 96-well microplate and $100 \mu \mathrm{l}$ of Z-buffer $\left(60 \mathrm{mM} \mathrm{Na} \mathrm{HPO}_{4}, 40 \mathrm{mM}\right.$ $\mathrm{NaH}_{2} \mathrm{PO}_{4}, 1 \mathrm{mM} \mathrm{MgSO}, 10 \mathrm{mM} \mathrm{KCl}, 2 \mathrm{mM} \mathrm{DTT}$, and $0.2 \%$ sarcosyl, adjusted to $\mathrm{pH} 7.0$ ), containing $1 \mathrm{mg} / \mathrm{ml}$ ONPG, was added to the plates with subsequent incubation at $37^{\circ} \mathrm{C}$ for $60 \mathrm{~min}$. Absorbance at wavelengths of 405 and $595 \mathrm{~nm}$ was measured using Micro Plate Reader Model 680 (BioRad Laboratories, Inc.) to estimate $\beta$ galactosidase activity as the amount of $o$-nitrophenol produced and yeast cell density, respectively. Agonistdependent lac $Z$ reporter induction was demonstrated as "an increase of induction", which was calculated using the following formula: $\left[\mathrm{OD}_{405}\right.$ (sample)/OD ${ }_{595}$ (sample)]-[OD 405 (DMSO)/OD 595 (DMSO)].

The antagonistic activities of chemicals were examined by competition between the antagonist and agonist added at the concentration of $\mathrm{EC}_{50}$. In the antagonist assays for ERs, E2 $(0.18 \mathrm{nM}$ and $0.022 \mathrm{nM}$ for the ER $\alpha$ expressing wild-type and $c w p 1 \Delta c w p 2 \Delta$ strains, and 0.14 $\mathrm{nM}$ and $0.037 \mathrm{nM}$ for the ER $\beta$-expressing wild-type and $c w p 1 \Delta c w p 2 \Delta$ strains, respectively) was mixed with test ligands. To examine antagonist effects on AR in yeast strains, testosterone $(24,21$, and $13 \mathrm{nM}$ for the wildtype, $c w p 1 \Delta p d r 5 \Delta$, and $p d r 5 \Delta p d r 10 \Delta$ strains, respectively) was used as an agonist with test compounds. In the PR antagonist assay, PS $(2.31,0.08$, and $0.15 \mu \mathrm{M}$ for the wild-type, $c w p 1 \Delta p d r 5 \Delta$, and $c w p 1 \Delta c w p 2 \Delta$ strains, respectively) was mixed with test ligands. The dosedependent repression of $l a c Z$ reporter expression by antagonists is shown as "relative activity" (\%), which was calculated using the following formula: $\left[\mathrm{OD}_{405}\right.$ (sample)/ $\mathrm{OD}_{595}$ (sample)]/[OD 405 (DMSO)/OD 595 (DMSO) $] \times$ 100. To distinguish antagonist activity from the nonspecific inactivation of gene expression, the CYC yeast strains established in W303a and corresponding mutants for each receptor that constitutively expressed the lac $Z$ reporter were used for comparisons.

\section{Extraction and concentration of synthetic sex hormone activities from oral tablets}

To test the sex hormone activities of pharmaceutical products, ten oral tablets of Lunabell ${ }^{\oplus}$ were ground into a fine powder in a mortar and suspended in methanol $(1 \mathrm{~g} / 12 \mathrm{ml})$ in polycarbonate tubes. These tubes were shaken for five minutes to extract organic substances. After centrifugation at $4000 \mathrm{rpm}$ for $5 \mathrm{~min}$, the supernatants were transferred to $1.5-\mathrm{ml}$ microtubes $(1 \mathrm{ml} /$ tube $)$ and dried using a vacuum concentrator. Extracts were redissolved in $15 \mu \mathrm{l}$ of DMSO and used for yeast reporter gene assays.

\section{Extraction and concentration of organic substances from urine}

The human biological sample, urine was provided from two independent donors, an adult male and female. Both donors gave written informed consent. To detect ER $\alpha$, $\mathrm{ER} \beta, \mathrm{AR}$, and PR ligand activities, $50 \mathrm{ml}$ of urine from the donors was filtered using a GF/C $47 \mathrm{~mm} \phi$ membrane (Whatman International Ltd., Maidstone, England) and acidified by adding $\mathrm{H}_{2} \mathrm{SO}_{4}$ at a final concentration of $0.5 \mathrm{M}$ for deconjugation. After an incubation at $60^{\circ} \mathrm{C}$ for $1 \mathrm{~h}$, urine samples were neutralized using $10 \mathrm{~N} \mathrm{NaOH}$ and flowed through a Waters Sep-pak Plus C18 Environmental cartridge (Waters Corporation, MA, USA). Bound substances were eluted from the cartridge with $2 \mathrm{ml}$ of DMSO at a flow rate of $1 \mathrm{ml} / \mathrm{min}$ and then dried using a vacuum concentrator. The extract was redissolved in $500 \mu \mathrm{l}$ of DMSO (i.e., concentration factor of 100). Samples were serially diluted and used as test samples in the yeast reporter gene assays. Data 
obtained from samples with the concentration factor of 50 were analyzed using the Student's $t$-test to assess significance between male and female urine. Probability $(p)$ values $<0.01$ were considered significant.

\section{Results}

Response to endogenous ligands of newly constructed sex hormone receptor-expressing yeast strains lacking CWPs and/or ABC transporter genes

The reporter gene assay yeast strains expressing human ER $\alpha, E R \beta, P R$, and AR established in wild-type W303a showed the dose-dependent induction of the lac $Z$ reporter gene in response to the human endogenous ligands, E2, PS, and TS, respectively (Fig. 1). The $\mathrm{EC}_{50}$ values of $\mathrm{ER} \alpha, \mathrm{ER} \beta, \mathrm{PR}$, and $\mathrm{AR}$ were $0.18 \mathrm{nM}, 0.14 \mathrm{nM}$, $2.31 \mu \mathrm{M}$, and $24.1 \mathrm{nM}$, respectively (Table 1 ); however, sensitivities were markedly lower than the reporter gene assay systems in mammalian cells [26]. Since the deletion of genes encoding CWPs (CWP1/CWP2) and/ or $\mathrm{ABC}$ transporter efflux pumps (PDR5/PDR10) on the plasma membrane enhanced the sensitivities of DNA damage-sensing yeasts and corticosteroid reporter gene assay yeasts [28, 33, 34], we used deletion mutants of these genes as hosts to establish new reporter gene assay strains. As shown in Fig. S1, stronger and more sensitive reporter gene expression was observed in most of the eleven $c w p / p d r$ mutants. Based on stronger liganddependent and weaker ligand-independent (background) reporter expression, $c w p 1 \Delta c w p 2 \Delta$ was selected as the most responsive mutant for $E R \alpha$ and $E R \beta$ assays; $c w p 1 \Delta c w p 2 \Delta$ and $c w p 1 \Delta p d r 5 \Delta$ for PR assays; and $c w p 1 \Delta p d r 5 \Delta$ and $p d r 5 \Delta p d r 10 \Delta$ for AR assays (Fig. S1).

Fig. 1 shows the dose-dependent induction of the lac $Z$ reporter gene against endogenous ligands in newlyconstructed mutant and wild-type yeast strains for the $\mathrm{ER} \alpha, \mathrm{ER} \beta, \mathrm{PR}$, and AR assays. The responses of ER $\alpha$ -
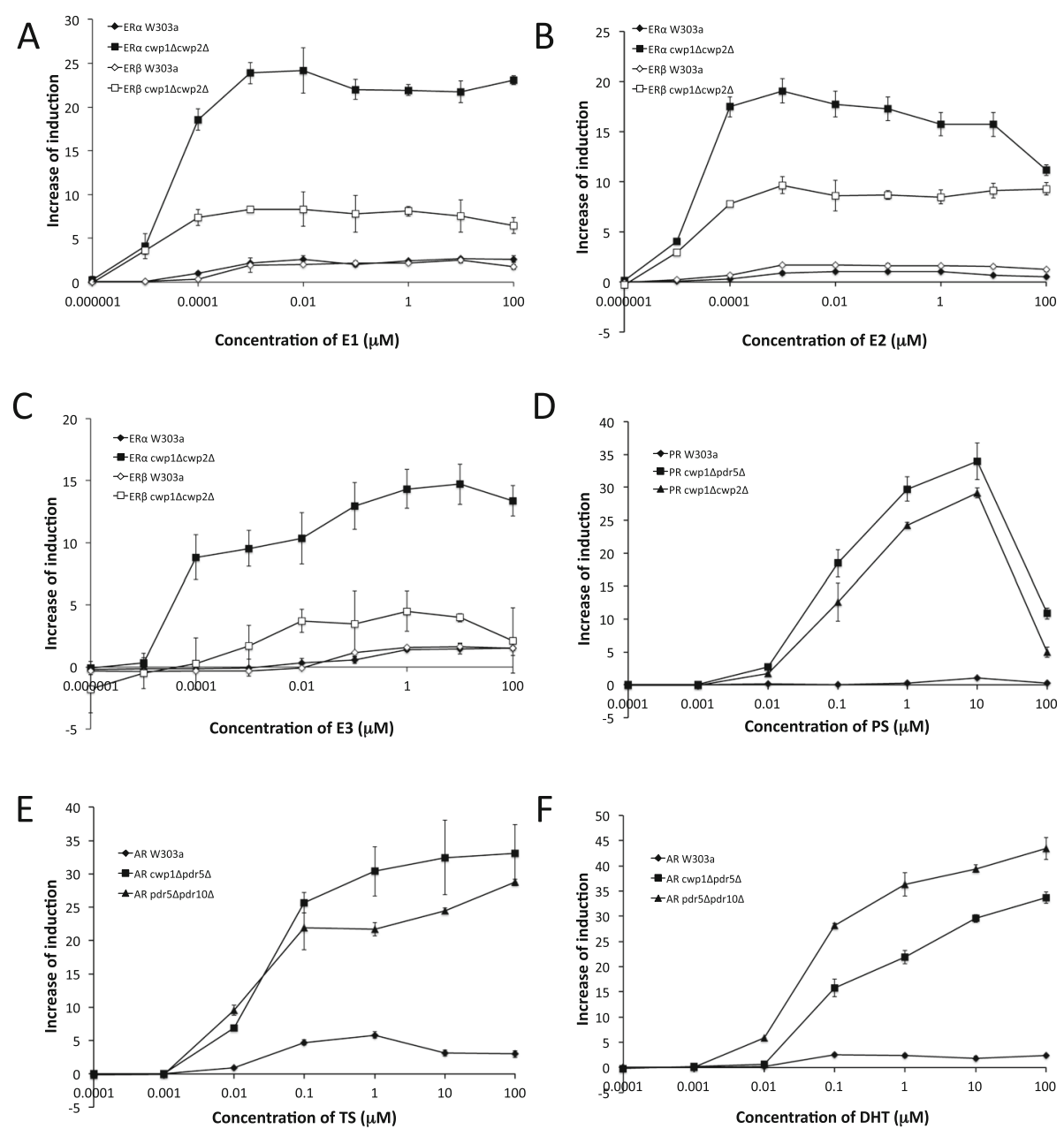

Fig. 1 Responses of reporter gene assay yeast strains expressing human ERa, ERR, PR, and AR to endogenous sex steroid hormones. ERa and ER $\beta$ assay yeasts (W303a and cwp 1 $\Delta$ cwp2 $\Delta$ ) were exposed to E1 (A), E2 (B), and E3 (C). PR (W303a, cwp 1 $\Delta p d r 5 \Delta$, and cwp 1 $\Delta c w p 2 \Delta$ ) and AR (W303a, cwp $1 \Delta p d r 5 \Delta$, and $p d r 5 \Delta p d r 10 \Delta$ ) assay yeasts were exposed to PS (D), TS (E), and DHT (F), respectively. The ligand-dependent induction of $\beta$-gal was measured as described in the Methods section. Data represent the mean \pm SD of triplicate experiments 
Table 1 Comparison of responses to endogenous agonist ligands among wild-type and various mutant yeast strains expressing sex steroid hormone receptors

\begin{tabular}{|c|c|c|c|c|}
\hline \multirow{2}{*}{$\begin{array}{l}\text { Ligand } \\
\text { Yeast strain }\end{array}$} & \multicolumn{4}{|l|}{ E1 } \\
\hline & ERa W303a & ERa cwp $1 \Delta c w p 2 \Delta$ & ERß W303a & $\operatorname{ER} \beta$ cwp $1 \Delta c w p 2 \Delta$ \\
\hline Fold difference $\left(10^{-3} \mu \mathrm{M}\right)$ & 1 & 10.9 & 1 & 4.3 \\
\hline Detection limit $(\mu \mathrm{M})$ & $10^{-4}$ & $10^{-5}$ & $10^{-4}$ & $10^{-5}$ \\
\hline $\mathrm{EC}_{50}(\mu \mathrm{M})$ & $1.20 \times 10^{-4}$ & $2.28 \times 10^{-5}$ & $2.51 \times 10^{-4}$ & $1.50 \times 10^{-5}$ \\
\hline Ligand & E2 & & & \\
\hline Yeast strain & ERa W303a & ERa cwp $1 \Delta c w p 2 \Delta$ & ERß W303a & $\operatorname{ER} \beta c w p 1 \Delta c w p 2 \Delta$ \\
\hline Fold difference $\left(10^{-3} \mu \mathrm{M}\right)$ & 1 & 21.7 & 1 & 5.7 \\
\hline Detection limit ( $\mu \mathrm{M})$ & $10^{-4}$ & $10^{-5}$ & $10^{-4}$ & $10^{-5}$ \\
\hline$E C_{50}(\mu \mathrm{M})$ & $1.84 \times 10^{-4}$ & $2.23 \times 10^{-5}$ & $1.42 \times 10^{-4}$ & $3.65 \times 10^{-5}$ \\
\hline Ligand & E3 & & & \\
\hline Yeast strain & ERa W303a & ERa cwp $1 \Delta c w p 2 \Delta$ & ERß W303a & $\operatorname{ER} \beta$ cwp $1 \Delta c w p 2 \Delta$ \\
\hline Fold difference $(1 \mu \mathrm{M})$ & 1 & 10.1 & 1 & 2.9 \\
\hline Detection limit $(\mu \mathrm{M})$ & 0.01 & $10^{-5}$ & 0.1 & $10^{-4}$ \\
\hline $\mathrm{EC}_{50}(\mu \mathrm{M})$ & 0.15 & $3.02 \times 10^{-5}$ & 0.034 & $1.22 \times 10^{-3}$ \\
\hline Ligand & PS & & & \\
\hline Yeast strain & PR W303a & PR cwp $1 \Delta p d r 5 \Delta$ & PR cwp $1 \Delta c w p 2 \Delta$ & \\
\hline Fold difference $(10 \mu \mathrm{M})$ & 1 & 34.2 & 29.4 & \\
\hline Detection limit $(\mu \mathrm{M})$ & 10 & 0.01 & 0.01 & \\
\hline $\mathrm{EC}_{50}(\mu \mathrm{M})$ & 2.31 & 0.08 & 0.15 & \\
\hline Ligand & TS & & & \\
\hline Yeast strain & AR W303a & AR cwp $1 \Delta p d r 5 \Delta$ & AR pdr5 $\Delta p d r 10 \Delta$ & \\
\hline Fold difference $(1 \mu \mathrm{M})$ & 1 & 5.2 & 3.7 & \\
\hline Detection limit $(\mu \mathrm{M})$ & 0.01 & 0.01 & 0.01 & \\
\hline $\mathrm{EC}_{50}(\mu \mathrm{M})$ & 0.024 & 0.021 & 0.013 & \\
\hline Ligand & DHT & & & \\
\hline Yeast strain & AR W303a & AR cwp $1 \Delta p d r 5 \Delta$ & AR pdr5 $\Delta p d r 10 \Delta$ & \\
\hline Fold difference $(100 \mu \mathrm{M})$ & 1 & 14.4 & 18.6 & \\
\hline Detection limit $(\mu \mathrm{M})$ & 0.01 & 0.01 & 0.01 & \\
\hline$E C_{50}(\mu \mathrm{M})$ & 0.028 & 0.011 & 0.023 & \\
\hline
\end{tabular}

Abbreviation used: $\mathrm{EC}_{50}, 50 \%$ effective concentration

and ER $\beta$-expressing $c w p 1 \Delta c w p 2 \Delta$ strains to the three endogenous estrogens E1, E2, and E3 and PR-expressing $c w p 1 \Delta c w p 2 \Delta$ or $c w p 1 \Delta p d r 5 \Delta$ strains to PS were markedly stronger than those of the corresponding receptorexpressing wild-type W303a strains: relative reporter activities markedly increased (3- to 34 -fold), while $\mathrm{EC}_{50}$ values (4- to 5000-fold) and the minimum detection limit (10- to 1000-fold) markedly decreased (Fig. 1 and Table 1). AR-expressing $c w p 1 \Delta p d r 5 \Delta$ and $p d r 5 \Delta p d r 10 \Delta$ strains also showed stronger relative reporter activities than the wild-type W303a strain (4- to 19-fold) (Fig. 1 and Table 1); however, $\mathrm{EC}_{50}$ values were only 1.2 - to 2.4-fold lower than those of the wild-type strain, and the minimum detection limit was not changed in the mutant and wild-type strains (Table 1). We also compared ligand potencies of endogenous estrogens and androgens in the yeast assay. E1 and E2 were more potent ligands than E3 in ER $\alpha$ - and ER $\beta$-expressing stains. E1 and E2 for ERs and TS and DHT for AR showed similar potencies in yeasts (Fig. 1. and Table 1).

\section{Cross-reactivity of newly constructed sex hormone receptor assay yeast strains against various steroid hormones}

To examine the ligand specificity of each receptor in the reporter yeast strains, we performed a reporter gene assay using sex hormones and corticosteroid hormones as ligands. Although their $\mathrm{EC}_{50}$ values were markedly higher than those of intrinsic primary ligands, some cross-activated other receptors and induced lacZ 
reporter gene expression (Table S-3). AR-expressing $c w p 1 \Delta p d r 5 \Delta$ and $p d r 5 \Delta p d r 10 \Delta$ mutant strains were activated by E2 and PS at doses higher than $0.1 \mu \mathrm{M}$, and maximum reporter activities were similar to those of $E R \alpha$ - and ER $\beta$-expressing mutant strains to E2 and those of PR-expressing mutant strains to PS (Fig. 1 and Fig. 2a, c). The cross-reactivity of AR to E2 and PS was markedly stronger in the mutants than in wild-type W303a
(14- to 38-fold stronger reporter activity and 10-fold lower minimum detection limit, data not shown). AR, particularly in $p d r 5 \Delta p d r 10 \Delta$, strongly responded to the other natural estrogen E1, but not to E3 (Fig. 2g and h). The ER $\beta$-expressing $c w p 1 \Delta c w p 2 \Delta$ mutant strain weakly responded to TS and PS at high doses (Fig. 2b and c). PR-expressing $c w p 1 \Delta c w p 2 \Delta$ and $c w p 1 \Delta p d r 5 \Delta$ mutant strains exhibited moderate reporter gene expression in
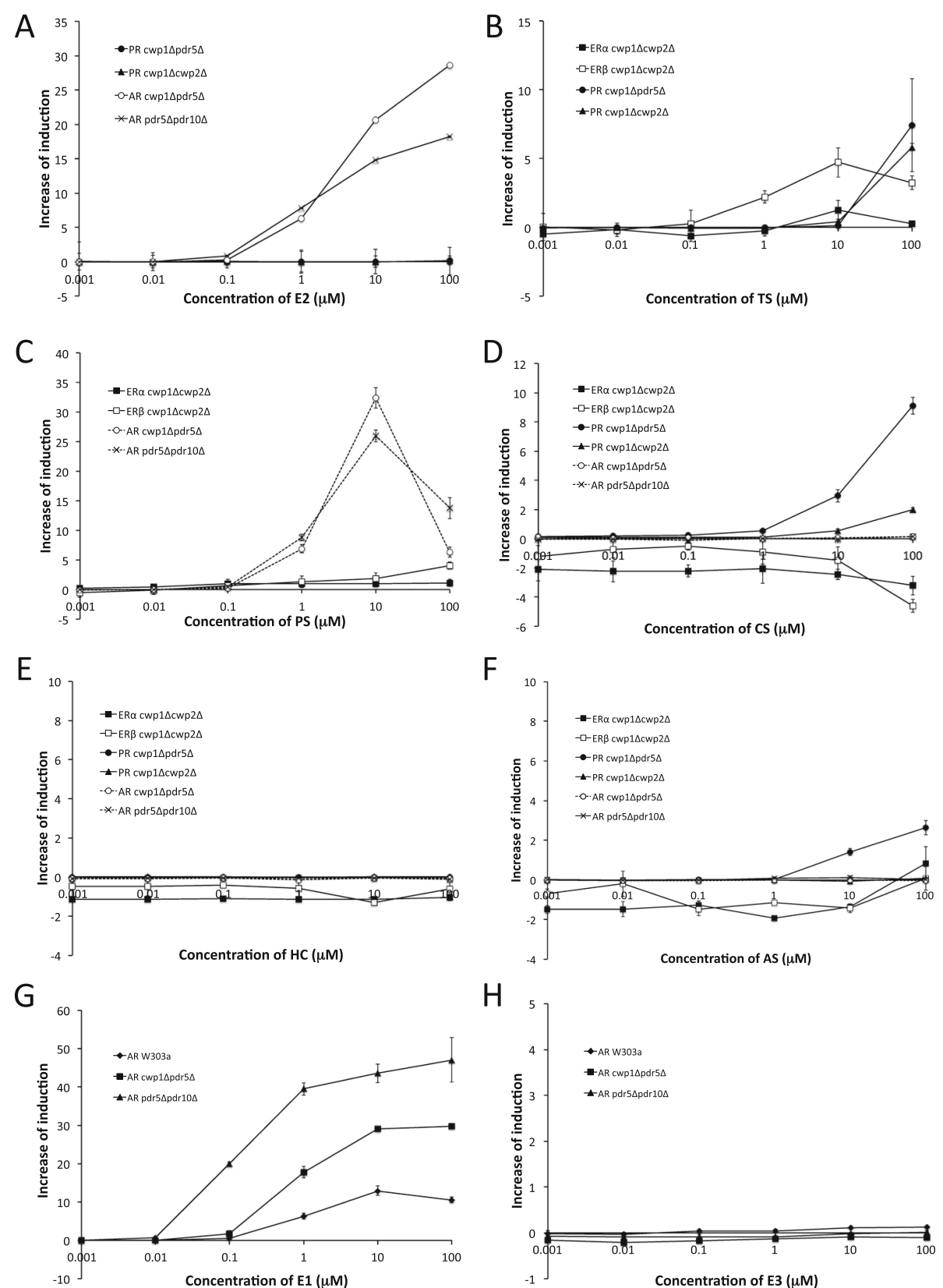

Fig. 2 Cross-reactivity of $c w p / p d r$ mutant reporter gene assay yeast strains expressing $E R a, E R B, P R$, and $A R$ against endogenous steroid hormones. (A-C) Responses to non-primary sex steroid hormones were examined: E2 for AR and PR (A), TS for ERa, ER $\beta$, and PR (B), and PS for $E R a, E R \beta$, and AR (C). (D-F) Responses to corticosteroids: CS (D), HC (E), and AS (F) for ERa, ERß, PR, and AR. Responses of AR assay yeasts to E1 and $\mathrm{E} 3$ were also examined $(\mathrm{G}$ and $\mathrm{H})$. The wild-type AR assay yeast was also used as a reference. Data represent the mean $\pm \mathrm{SD}$ of triplicate experiments 
response to TS and the corticosteroids, CS and AS, at high doses (Fig. 2b, d-f). ER $\alpha$-expressing cwp $1 \Delta c w p 2 \Delta$ strains did not respond to any steroid hormone other than estrogens (Fig. 2 and Table S-3).

\section{Detection of agonist activities of synthetic ligands in ERa,} $E R \beta$, and AR assay yeast strains

We tested the responses of ER $\alpha$ - and ER $\beta$-expressing yeast strains to the synthetic agonist ligands EE2 and DES, and two selective ER modulators (SERMs), PPT and DPN. EE2 is bioactive and is the most widely used synthetic estrogen for hormone therapy with oral and transdermal administration commonly used worldwide $[44,45]$. DES was the first orally active synthetic non-steroidal estrogen prescribed to pregnant women to reduce the risk of abortion between the 1940s to 1970s in Western countries. However, it is now known as a teratogen and carcinogen because of its detrimental effects in humans [46, 47]. PPT activates ER $\alpha$, but not ER $\beta$, while DPN shows higher selectivity for $E R \beta$ than for ER $\alpha$ [48-50].

ER $\alpha$ - and ER $\beta$-expressing $c w p 1 \Delta c w p 2 \Delta$ strains exhibited stronger responses to EE2 with markedly lower $\mathrm{EC}_{50}$ values than those of the wild-type W303a strain (Fig. 3a and Table 2). In ER $\alpha$ - and ER $\beta$-expressing W303a, reporter activities induced by DES and two SERMs were very low, even at high doses. The responses of both ERs to these ligands were markedly stronger in $c w p 1 \Delta c w p 2 \Delta$, with lower $\mathrm{EC}_{50}$ values and detection limit and increased reporter activities (Fig. 3b-d and Table 2). The subtype-selective ligand activity of SERMs was also detectable in the $c w p 1 \Delta c w p 2 \Delta$ strain. DPN showed selectivity for $E R \beta$ as previously reported, with a 35.5- and 10-fold lower $\mathrm{EC}_{50}$ value and detection limit, respectively, than ER $\alpha$. PPT activated not only ER $\alpha$, but also $\mathrm{ER} \beta$ : the $\mathrm{EC}_{50}$ value and minimum detection limit for $E R \alpha$ were 2.5 and 10-fold lower, respectively, than those for ER $\beta$ (Fig. 3c, $d$ and Table 2).

We then performed a reporter gene assay to examine the responses of AR-expressing strains to synthetic ligands known as anabolic androgenic steroids [51-55]. As shown in Fig. 4, the mutant strains $c w p 1 \Delta p d r 5 \Delta$ and $p d r 5 \Delta p d r 10 \Delta$ expressing AR responded to synthetic ligands more strongly than the wild-type W303a strain. The AR-expressing $c w p 1 \Delta p d r 5 \Delta$ strain showed stronger responses to TBA and STA than the $p d r 5 \Delta p d r 10 \Delta$ strain, while the AR-expressing $p d r 5 \Delta p d r 10 \Delta$ strain was more responsive to $17 \alpha$-MAS and $17 \alpha$-MTS than the $c w p 1 \Delta p d r 5 \Delta$ strain (Fig. 4a-e and Table 2). We also showed that AR strains, particularly mutant strains, detected the synthetic estrogen EE2 (Fig. 4f) as well as the natural estrogens E1 and E2 (Fig. 2a, g and Table 2).

\section{Responses of estrogen receptor assay yeast strains to known antagonist ligands}

We investigated the responses of newly-constructed yeast strains expressing ER $\alpha$ and $\operatorname{ER} \beta$ to known
A

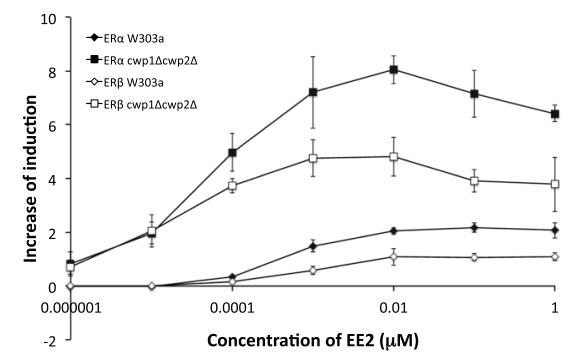

C

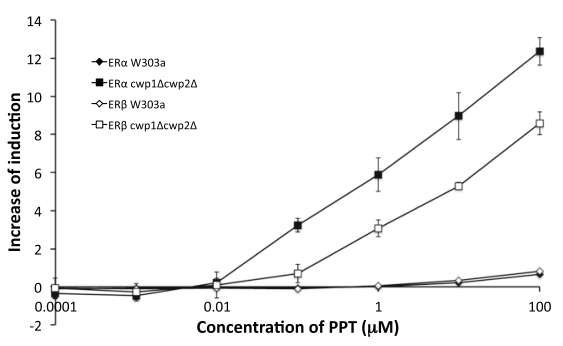

B

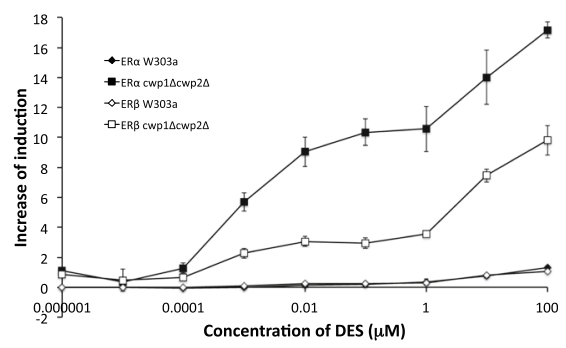

D

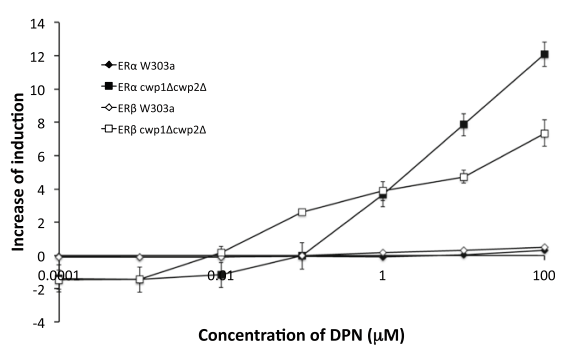

Fig. 3 Responses of reporter gene assay yeast strains expressing ERa and ER $\beta$ (W303a and cwp 1 $\Delta c$ wp $2 \Delta$ ) to synthetic estrogens. ERa and ER assay yeasts were exposed to EE2 (A), DES (B), PPT (C), and DPN (D). In the assay of these ligands, medium composition was changed from that used for other estrogen assays to reduce ligand-independent $\beta$-gal activity (data not shown, see Materials and Methods for details). Data represent the mean \pm SD of triplicate experiments 
Table $2 \mathrm{EC}_{50}$ values $(\mu \mathrm{M})$ of synthetic ligands in yeast strains expressing human $E R a, E R \beta$, and $A R$

\begin{tabular}{|c|c|c|c|c|c|c|c|}
\hline \multirow[t]{2}{*}{ Receptor } & \multirow[t]{2}{*}{ Strains } & \multicolumn{6}{|l|}{ Ligands } \\
\hline & & E2* & EE2 & DES & PPT & DPN & \\
\hline \multirow[t]{2}{*}{ ERa } & W303a & $7.66 \times 10^{-4}$ & $6.34 \times 10^{-4}$ & 4.20 & 18.42 & 26.04 & \\
\hline & cwp $1 \Delta c w p 2 \Delta$ & $8.34 \times 10^{-5}$ & $4.22 \times 10^{-5}$ & 3.91 & 0.92 & 3.16 & \\
\hline \multirow[t]{2}{*}{ ER $\beta$} & W303a & $1.89 \times 10^{-4}$ & $6.59 \times 10^{-4}$ & $8.31 \times 10^{-4}$ & 13.71 & 3.54 & \\
\hline & cwp $1 \Delta c w p 2 \Delta$ & $5.89 \times 10^{-5}$ & $1.76 \times 10^{-5}$ & $8.50 \times 10^{-4}$ & 2.34 & 0.089 & \\
\hline \multirow[t]{2}{*}{ Receptor } & Strains & Ligands & & & & & \\
\hline & & 17a-MAS & $17 \beta-H$ & $17 a-M T S$ & TBA & STA & EE2 \\
\hline \multirow[t]{3}{*}{$A R$} & W303a & 0.010 & 0.032 & 11.6 & 0.10 & 0.019 & 6.47 \\
\hline & cwp $1 \Delta p d r 5 \Delta$ & 0.027 & 0.019 & 0.078 & 0.031 & 0.022 & 2.88 \\
\hline & $p d r 5 \Delta p d r 10 \Delta$ & $3.10 \times 10^{-3}$ & 0.016 & 0.023 & 0.75 & 0.021 & 1.88 \\
\hline
\end{tabular}

* Dose-response curve of ERa- and ERß-expressing yeast strains against E2 assayed in exposure condition for synthetic estrogens was presented in Fig. S2
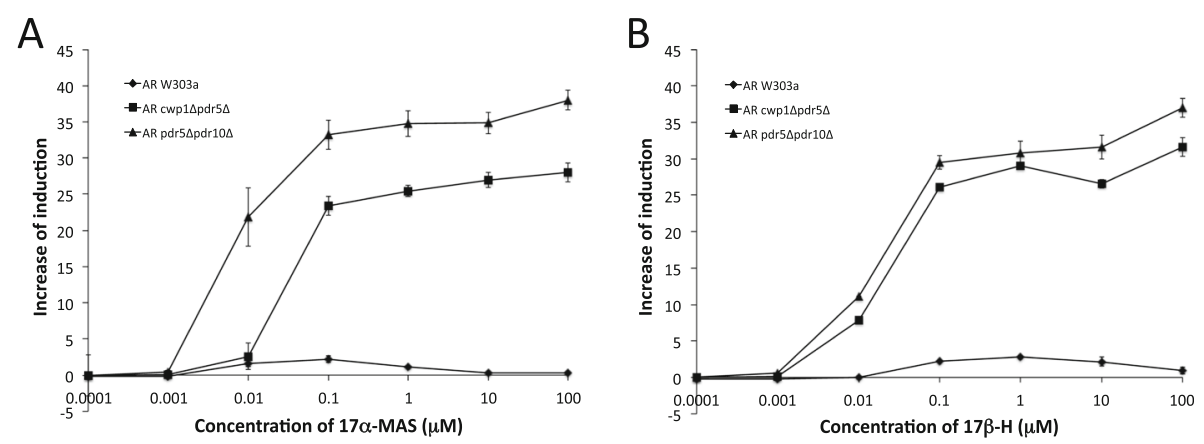

C

D
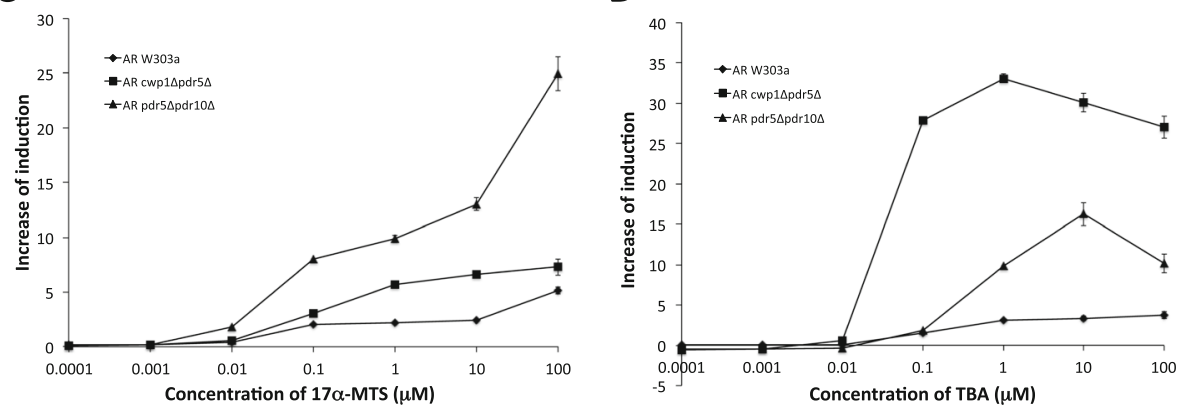

$E$
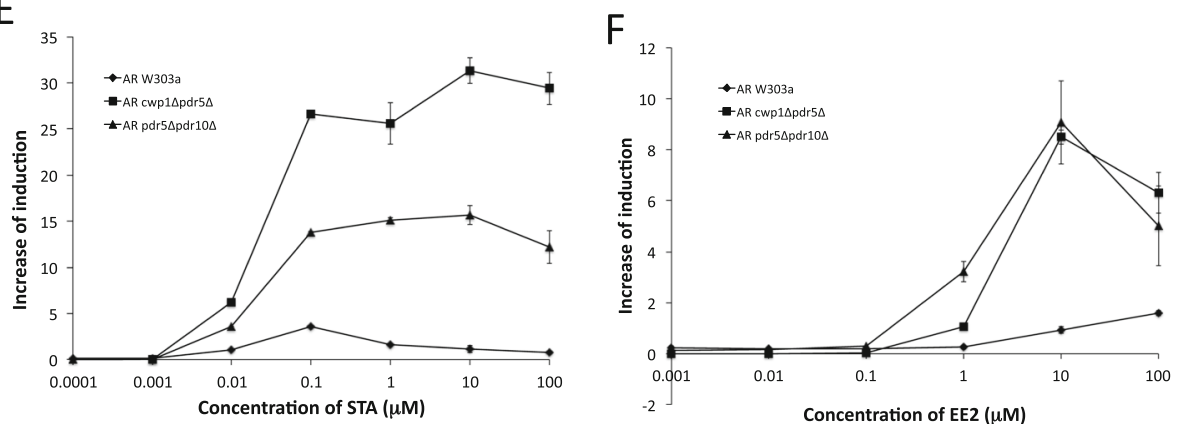

Fig. 4 Responses of reporter gene assay yeast strains expressing AR (W303a, $c w p 1 \Delta p d r 5 \Delta$, and $p d r 5 \Delta p d r 10 \Delta)$ to synthetic androgens and EE2. AR assay yeasts were exposed to 17a-MAS (A), 17ß-H (B), 17a-MTS (C), TBA (D), STA (E), and EE2 (F). Data represent the mean \pm SD of triplicate experiments 
antagonistic ligands by simultaneously exposing them to the agonist E2: $0.18 \mathrm{nM}$ and $0.022 \mathrm{nM}$ for the ER $\alpha$ expressing wild-type and $c w p 1 \Delta c w p 2 \Delta$ strains, and 0.14 $\mathrm{nM}$ and $0.037 \mathrm{nM}$ for the ER $\beta$-expressing wild-type and cwp $1 \Delta c w p 2 \Delta$ strains, respectively. The strains CYC W303a and CYC cwp $1 \Delta c w p 2 \Delta$, which constitutively express $\beta$-galactosidase, were used as references (see Materials and Methods for details). As shown in Fig. 5a, E2-dependent transactivation activity was moderately inhibited by ICI in ER $\alpha$ - and ER $\beta$-expressing cwp $1 \Delta c w p 2 \Delta$ strains (Fig. 5a and Table S-4). Constitutive $\beta$-gal expression was not repressed by ICI in control CYC strains up to $100 \mu \mathrm{M}$ (Fig. 5a). In the Tam assay, antagonist activity was detectable in ER $\alpha$-expressing W303a and $c w p 1 \Delta c w p 2 \Delta$, and in ER $\beta$-expressing $c w p 1 \Delta c w p 2 \Delta$. At a concentration of $100 \mu \mathrm{M}$, the expression of $\beta$-gal was almost completely inhibited in $E R \alpha$ and ER $\beta$-expressing $c w p 1 \Delta c w p 2 \Delta$. Although Tam also inhibited the constitutive expression of $\beta$-gal in CYC strains at $100 \mu \mathrm{M}$, this inhibitory effect was markedly
A

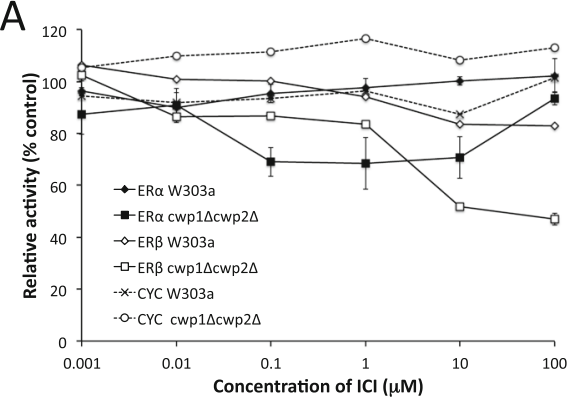

C

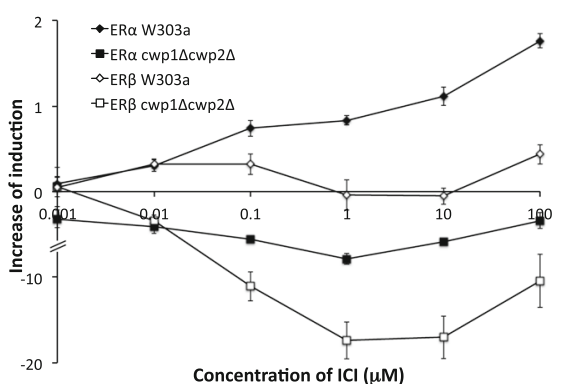

$\mathrm{E}$

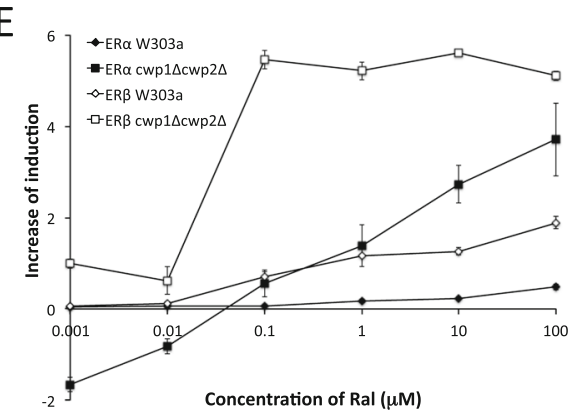

G

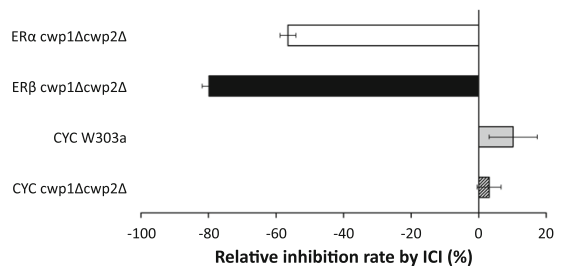

B

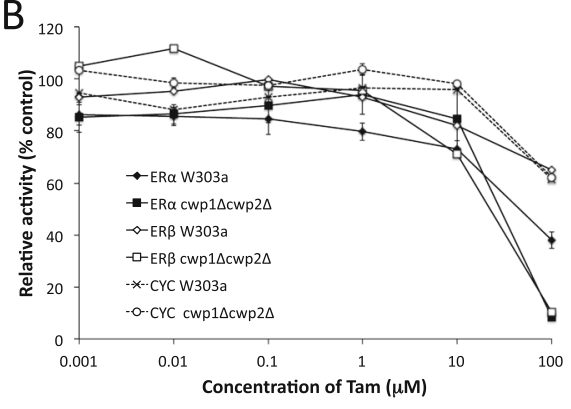

D $\left.{ }^{15}\right] \rightarrow$ ERa W303a

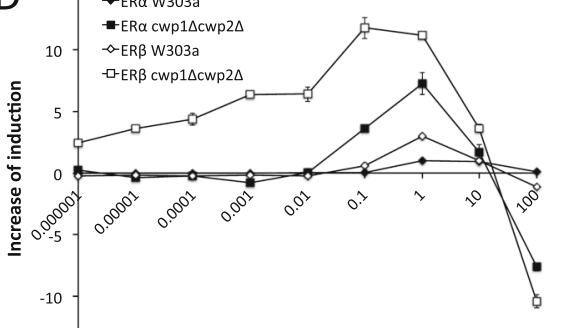

Concentration of Tam $(\mu \mathrm{M})$

$\mathrm{F}$

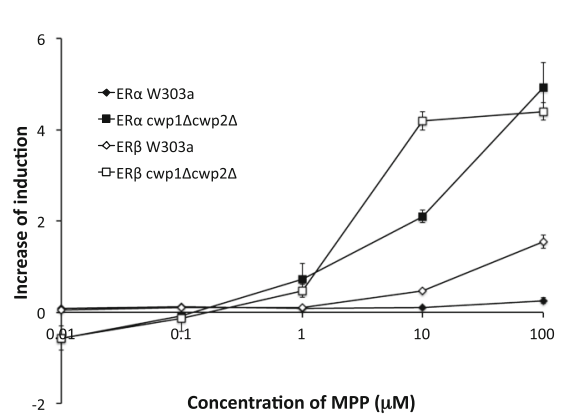

$\mathrm{H}$

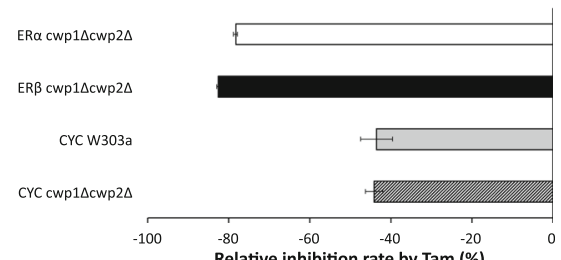

Fig. 5 Responses of reporter gene assay yeast strains expressing ERa and ERß (W303a and cwp $1 \Delta c w p 2 \Delta$ ) to known antagonist ligands. ERa and ER $\beta$ assay yeasts were exposed to ICI (A and C), Tam (B and D), Ral (C), and MPP (F). Antagonistic activity (A and B) and partial agonist activity (CF) were measured. Regarding ICl and MPP, inverse agonist activity was also measured: ICI (G) and Tam (H). CYC yeasts (W303a and cwp1 $\Delta$ cwp2 $\Delta$ ) that constitutively express $\beta$-gal were used as references in antagonist and inverse agonist assays. Data represent the mean \pm SD of triplicate experiments 
stronger in both ER-expressing yeast strains (Fig. 5b). These results indicate that the antagonistic activity of ICI and Tam was detectable in ER $\alpha$ and ER $\beta$-expressing cwp $1 \Delta c w p 2 \Delta$ strains (Fig. 5a, b, and Table S-4). In contrast to ICI and Tam, the antagonistic activity of Ral and MPP was undetectable in the yeast reporter gene assay (data not shown). We also performed an agonist assay using these four chemicals as ligands. ER $\alpha$ - and ER $\beta$ expressing yeast strains dose-dependently detected the partial agonist activities of ICI, Tam, Ral, and MPP. The responses observed were markedly stronger in $c w p 1 \Delta c w p 2 \Delta$ than in W303a strains (except for the ICI assay). (Fig. 5c-f and Table S-5). However, ER $\alpha$ - and ER $\beta$-expressing $c w p 1 \Delta c w p 2 \Delta$ strains showed unexpected responses to ICI and Tam. Reporter activity was abolished at some doses (ICI up to $1 \mu \mathrm{M}$, and Tam at $100 \mu \mathrm{M}$ ) in agonist assay (Fig. 5c and d). This observation suggests that basal $\beta$-gal expression levels due to ligand-independent transactivation activity of ER $\alpha$ and ER $\beta$ were inhibited by ICI and Tam.

To clarify whether ER $\alpha$ - and ER $\beta$-expressing $c w p 1 \Delta c w p 2 \Delta$ strains detected the inverse agonist activity of these chemicals [56, 57], we performed an agonist assay using ER $\alpha$ - and ER $\beta$-expressing cwp $1 \Delta c w p 2 \Delta$ strains along with the control CYC strains constitutively expressing $\beta$-gal. ICI strongly inhibited basal $\beta$-gal expression by ER $\alpha$ and $\mathrm{ER} \beta$ in $c w p 1 \Delta c w p 2 \Delta$ at $1 \mu \mathrm{M}$, while constitutive $\beta$-gal activity was not affected in CYC strains (Fig. 5g). When Tam was exposed at $100 \mu \mathrm{M}$, constitutive $\beta$-gal expression in control CYC yeasts was reduced to less than $60 \%$, showing cytotoxic effects. However, basal $\beta$-gal levels were strongly inhibited in $E R \alpha$ - and ER $\beta$-expressing $c w p 1 \Delta c w p 2 \Delta$ strains: residual $\beta$-gal activity was $\sim 20 \%$ (Fig. 5 h). These results indicated that the inverse agonist activity of ICI and Tam on ERs was detectable in the yeast reporter gene assay.

\section{Examination of ligand activities of Mif and Spi for PR, and flu and Zer for AR in yeast reporter gene assays}

We examined the antagonist and partial agonist activities of Mif and Spi as well as Flu and Zer in the PRand AR-expressing yeast strains, respectively (Fig. 6 and Table S-4 and S-5). The antagonist assay was performed by co-exposing test compounds with agonist ligands: PS for PR-expressing assay yeasts $(2.31,0.08$, and $0.15 \mu \mathrm{M}$ for the wild-type, $c w p 1 \Delta p d r 5 \Delta$, and $c w p 1 \Delta c w p 2 \Delta$ strains, respectively) and TS for AR assay yeasts $(24,21$, and $13 \mathrm{nM}$ for the wild-type, $c w p 1 \Delta p d r 5 \Delta$, and $p d r 5 \Delta p d r 10 \Delta$ strains, respectively), as described above. The constitutive expression of $\beta$-gal was not affected by these ligands in the reference CYC strains, CYC W303a, CYC cwp $1 \Delta p d r 5 \Delta$, CYC cwp $1 \Delta c w p 2 \Delta$, and CYC $p d r 5 \Delta p d r 10 \Delta$ (Fig. 6a, c, e, and g). Mif, a known anti-PS compound with anti-glucocorticoid activity [58] effectively inhibited PS-induced $\beta$-gal expression in PRexpressing $c w p 1 \Delta c w p 2 \Delta$ and $c w p 1 \Delta p d r 5 \Delta$ strains. Spi, an antagonist ligand for MR and GR [26, 28, 58] with weak progestational and anti-androgenic activities slightly inhibited PS-dependent $\beta$-gal expression in the PR-expressing cwp $1 \Delta p d r 5 \Delta$ strain (Fig. 6a and c, and Table S-4). In the agonist assay, the PR-expressing $c w p 1 \Delta p d r 5 \Delta$ strain weakly responded to Spi at $100 \mu \mathrm{M}$, but not to Mif (Fig. 6b and d, and Table S-5).

The activities of the known anti-androgenic ligands Flu and Zer were examined in AR assay yeast strains (Fig. 6e-h, and Table S-4). Flu is a specific antagonist for AR [59]. Zer is an anabolic estrogen produced in mycota (mycoestrogen), which is employed for livestock breeding and undescended testicles. Zer is a strong estrogenic metabolite derived from zearalenone, a non-steroidal mycoestrogen produced by Fusarium that induces reproductive disorders in domestic animals with estrogenic and anti-androgenic activities [60]. Both chemicals exerted inhibitory effects on TS-induced $\beta$-gal activity in a dose-dependent manner (Fig. 6e and g). However, responses to these ligands did not improve as expected in the $c w p 1 \Delta p d r 5 \Delta$ and $p d r 5 \Delta p d r 10 \Delta$ strains (Table S-4). AR-expressing $p d r 5 \Delta p d r 10 \Delta$ strains weakly responded to Flu and Zer at $100 \mu \mathrm{M}$ in the agonist assay (Fig. $6 \mathrm{f}$ and $h$, and Table S-5).

\section{Detection of progestational, androgenic, and anti- androgenic activities of progestins in various drug developmental generations}

Progestins, a class of synthetic PS, have been used as pharmaceuticals for birth control and the treatment of endometriosis. However, their androgenic activity may cause adverse side effect that is associated with change of lipid metabolism, in particular decrease of highdensity lipoprotein cholesterol (HDL) levels and increased risks of cardiovascular diseases [61]. Progestins developed in later generations were less androgenic. Moreover, fourth generation progestins acquired antiandrogenic activity $[62,63]$. We tested seven progestins from various generations for the detection of progestational and androgenic activities in PR- and ARexpressing yeast strains: MPA (unclassified), NET (first generation), LNG (second generation), DSG and GTD (third generation), and DNG and DRSP (fourth generation).

In the agonist assay, the responses of the PRexpressing W303a strain to MPA, LNG, DSG, DNG, and DRSP, and those of the AR-expressing W303a strain to GTD and DRSP were weak. The PR- and AR-expressing mutant yeast strains exhibited markedly stronger responses to all seven progestins (Fig. 7a-n). PR agonist activity was more potent than AR agonist activity for the progestins, except DSG (Table 3). A high dose of DSG 

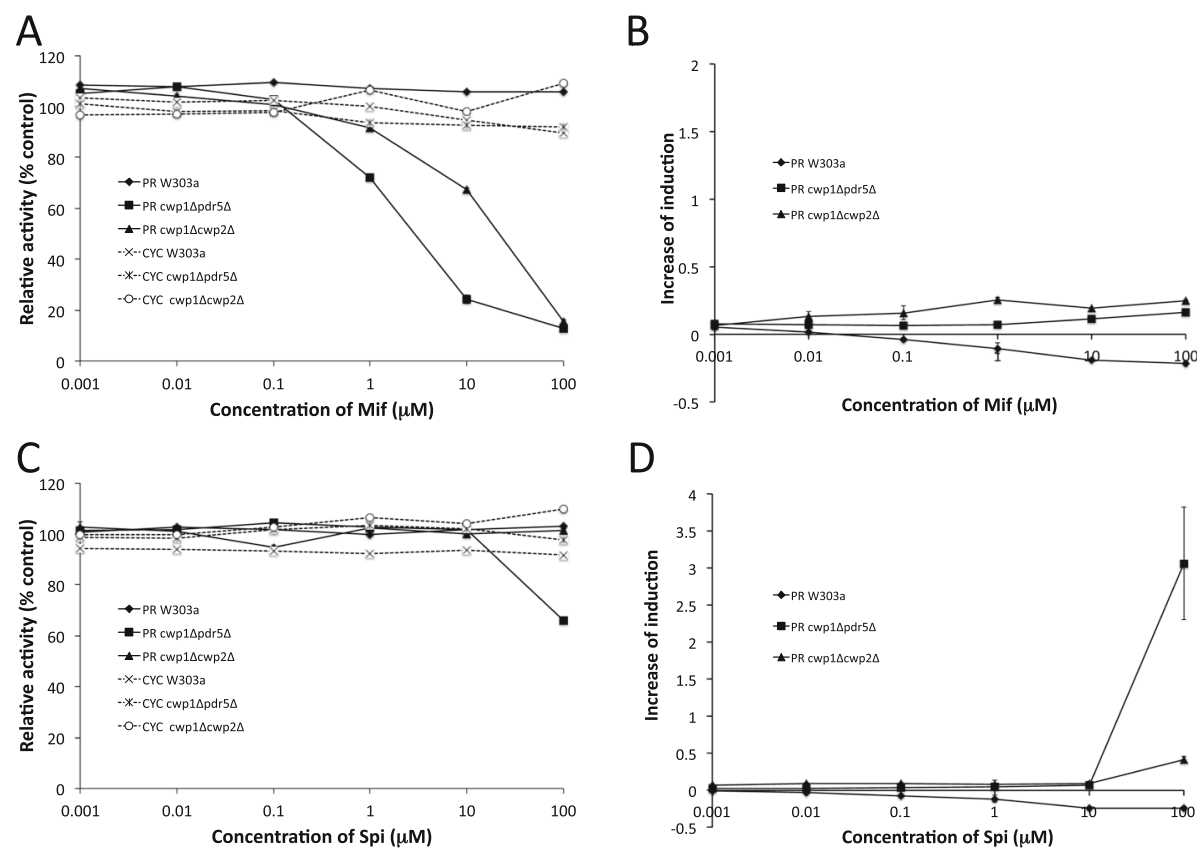

D

$E$

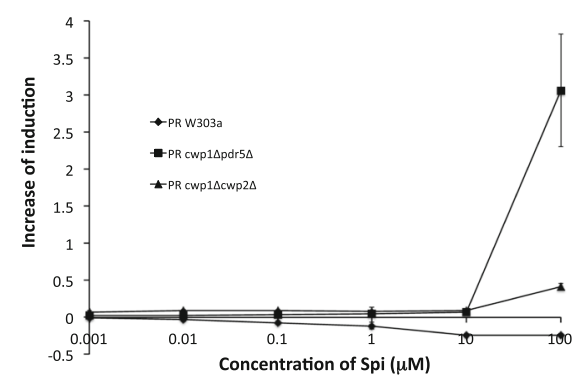

$\mathrm{F}$
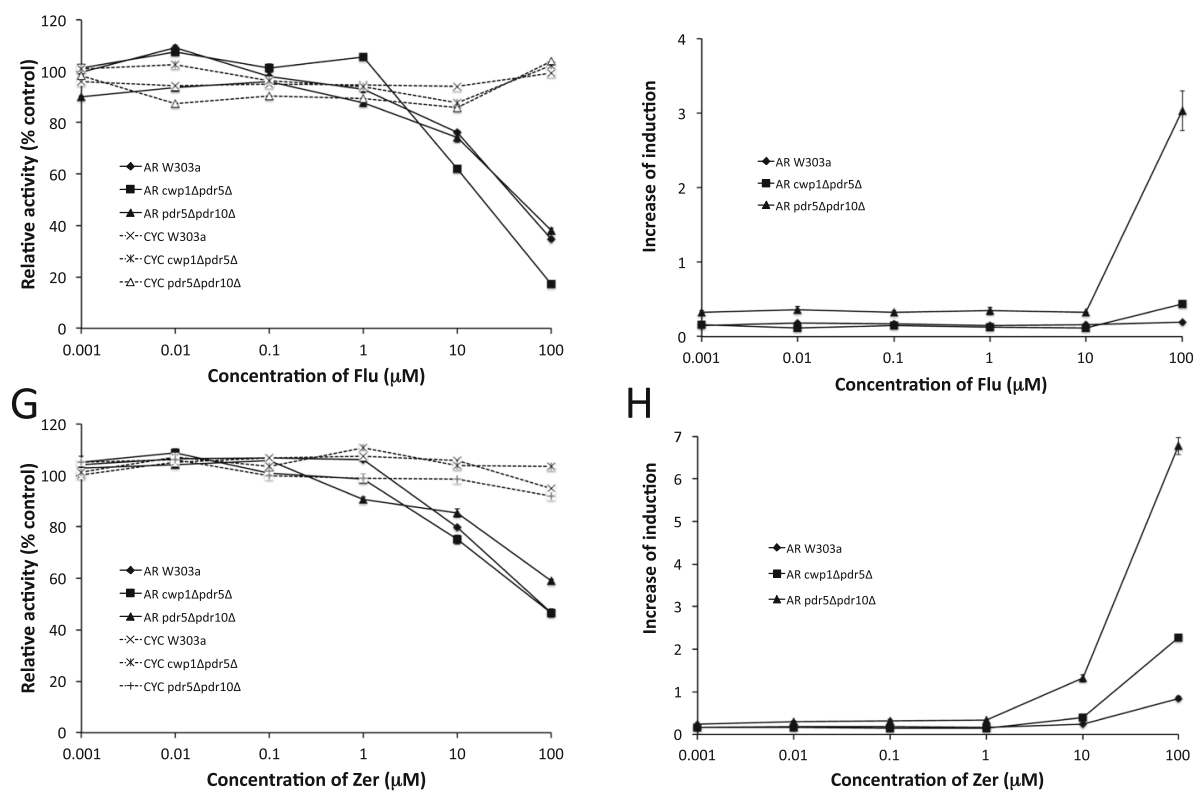

$\mathrm{H}$

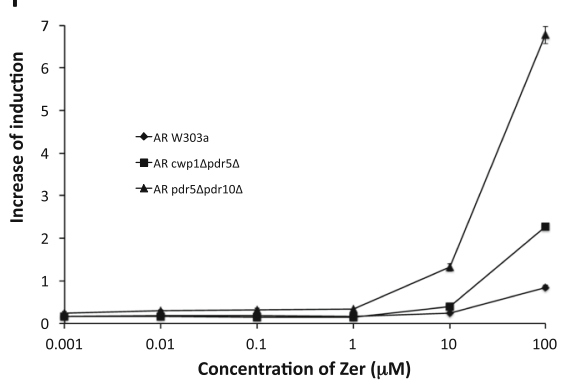

Fig. 6 Responses of reporter gene assay yeast strains expressing PR (W303a, cwp 1 $\Delta p d r 5 \Delta$, and $c w p 1 \Delta c w p 2 \Delta$ ) and AR (W303a, cwp $1 \Delta p d r 5 \Delta$, and $p d r 5 \Delta p d r 10 \Delta$ ) to known antagonist ligands. PR assay yeasts were exposed to Mif (A and B) and Spi ( $C$ and $D)$, and AR assay yeasts were exposed to Flu (E and F) and Zer ( $G$ and $H)$. Antagonistic activity $(A, C, E$, and $G$ ) and partial agonist activity $(B, D, F$, and $H)$ were measured. CYC yeasts (W303a, cwp $1 \Delta p d r 5 \Delta, c w p 1 \Delta c w p 2 \Delta$, and $p d r 5 \Delta p d r 10 \Delta$ ) were used as references in antagonist assays. Data represent the mean \pm SD of triplicate experiments

markedly reduced reporter activity due to cytotoxicity in mutant assay yeast strains (Fig. $7 \mathrm{~g}$ and $\mathrm{h}$ ). In comparisons among generations of progestins, PR-expressing mutant yeast strains more strongly responded to the third generation progestin GTD than the earlier generation progestins, MPA, NET, and LNG. Another third generation progestin DSG and the fourth generation progestins DNG and DRSP exhibited markedly weaker agonist potencies for PR than other progestins (Fig. 7a, c, e, g, i, $\mathrm{k}$ and $\mathrm{m}$ ). The PR-expressing cwp $1 \Delta p d r 5 \Delta$ strain was more responsive to MPA, NET, GTD, and DNG than the $c w p 1 \Delta c w p 2 \Delta$ strain. The responses of AR-expressing mutant yeast strains showed that the androgenic activities of the third generation progestins 


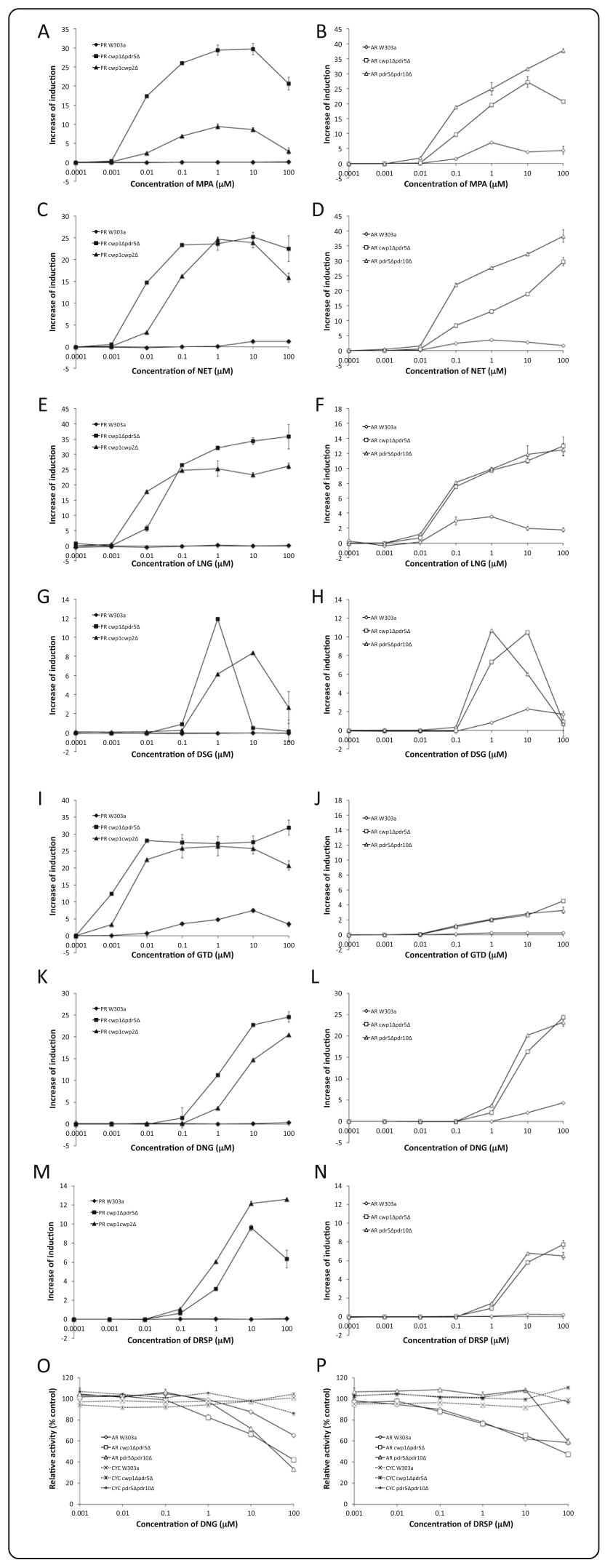

Fig. 7 Responses of reporter gene assay yeast strains expressing PR (W303a, cwp $1 \Delta p d r 5 \Delta$, and cwp $1 \Delta c w p 2 \Delta$ ) and AR (W303a, cwp $1 \Delta p d r 5 \Delta$, and $p d r 5 \Delta p d r 10 \Delta$ ) against progestins from various generations. PR and AR assay yeasts were exposed to MPA (A and B), NET (C and D), LNG (E and F), DSG (G and H), GTD (I and J), DNG ( $K$ and $L$ ), and DRSP ( $M$ and N). Progestational activity ( $A, C, E, G, I, K$, and $\mathrm{M})$ and androgenic activity (B, D, F, H, J, L, and N) were measured. The anti-androgenic activities of DNG $(\mathrm{O})$ and DSRP (P) were also measured by antagonist assays using AR assay yeasts. CYC yeasts (W303a, cwp $1 \Delta p d r 5 \Delta$, and $p d r 5 \Delta p d r 10 \Delta$ ) were used as references. Data represent the mean \pm SD of triplicate experiments

DSG and GTD and fourth generation progestins DNG and DRSP were 10- and 100-fold weaker, respectively, than earlier generation progestins with respect to the minimal detection limit concentration (Fig. $7 b, d, f, h, j$, $\mathrm{l}$, and $\mathrm{n}$ ).

We also performed an antagonist assay to detect the anti-androgenic activities of the fourth generation progestins DNG and DRSP using AR-expressing strains and reference CYC strains. Neither DNG nor DRSP inhibited the constitutive expression of $\beta$-gal in CYC strains. In contrast, the dose-dependent inhibition of TS-induced $\beta$-gal activity was observed in AR-expressing yeast strains exposed to these compounds. Sensitivity for DNG was improved in mutant assay yeasts expressing AR, while the response to DRSP was similar between the wild-type W303a and mutant assay yeast strains (Fig. 7o and $\mathrm{p}$, and Table S-6).

\section{Validation of newly constructed sex steroid hormone receptor assay yeast strains}

We investigated whether steroid hormone activities were detectable from oral pharmaceutical tablets and human urine samples to validate the newly established reporter gene assay strains for human sex steroid receptors. Organic compounds were extracted and concentrated from the oral tablets and urine containing synthetic and endogenous sex hormones, respectively, and reporter gene assays were performed using the prepared samples as ligands. Lunabell ${ }^{\circ}$ was developed for the treatment of dysmenorrhea associated with endometriosis. It contains EE2 and NET as pharmaceutically active ligands. As shown in Fig. 8, the assay strains established in wild-type W303a barely detected hormone activities from Lunabell ${ }^{\circ}$, except for the ER $\beta$-expressing strain. The mutant yeast strains for all four sex hormone receptors detected ligand activities from the tablets, with a more than 10fold lower detection limit.

We then examined whether sex hormone activities in human urine were detectable in the yeast reporter gene assays. The ER $\beta$-expressing wild-type W303a strain weakly responded, and the ER $\alpha$ - and AR-expressing W303a strain barely detected ligand activities in urine. 
Table $3 \mathrm{EC}_{50}$ values $(\mu \mathrm{M})$ of progestins in yeast strains expressing human PR and AR

\begin{tabular}{|c|c|c|c|c|c|c|c|c|}
\hline \multirow[t]{2}{*}{ Receptor } & \multirow[t]{2}{*}{ Strains } & \multicolumn{7}{|l|}{ Ligands } \\
\hline & & MPA & NET & LNG & DSG & GTD & DNG & DRSP \\
\hline \multirow[t]{3}{*}{$P R$} & W303a & n. d. & 2.92 & n. d. & n. d. & 0.22 & n. c. & n. d. \\
\hline & cwp $1 \Delta p d r 5 \Delta$ & $9.70 \times 10^{-3}$ & $9.51 \times 10^{-3}$ & 0.023 & 0.29 & $9.96 \times 10^{-4}$ & 0.86 & 1.78 \\
\hline & $c w p 1 \Delta c w p 2 \Delta$ & 0.44 & 0.07 & $3.06 \times 10^{-4}$ & 0.30 & $2.59 \times 10^{-3}$ & 6.1 & 0.80 \\
\hline \multirow[t]{3}{*}{$A R$} & W303a & 0.23 & 0.093 & 0.030 & 1.65 & n. c. & 9.78 & n. c. \\
\hline & cwp $1 \Delta p d r 5 \Delta$ & 0.28 & 0.16 & 0.028 & 0.32 & 1.06 & 8.10 & 7.39 \\
\hline & $p d r 5 \Delta p d r 10 \Delta$ & 0.084 & 0.087 & 0.026 & 0.31 & 0.40 & 2.43 & 2.32 \\
\hline
\end{tabular}

Abbreviation used: $n$. d. not detectable, n. c. not calculable

The mutant assay strains expressing these receptors clearly showed reporter activities. None of the PR assay strains responded to urine samples (Fig. 9). In comparisons of male and female urine samples, ER $\alpha$ and ER $\beta$-expressing $c w p 1 \Delta c w p 2 \Delta$ strains were slightly more responsive to female urine than to male samples ( 1.5-fold). In contrast, AR-expressing $c w p 1 \Delta p d r 5 \Delta$ and pdr5 $\Delta$ odr $10 \Delta$ strains showed markedly stronger responses to female samples than to male samples (Fig. 9). Reporter activity between male and female urine samples were significantly different in AR-expressing $c w p 1 \Delta p d r 5 \Delta(p<0.0005)$ and $p d r 5 \Delta o d r 10 \Delta(p<0.001)$ strains.

\section{Discussion}

S. cerevisiae is the simplest eukaryotic organism that possesses highly conserved gene expression systems with those of higher eukaryotes, including humans [64]. The mechanisms of action of NRs in animal cells may be reconstituted in yeast cells by introducing NRs and transcriptional coactivator genes, along with reporter plasmids containing appropriate response elements [27, 28, 41, 65-69]. In the present study, we established new reporter gene assay systems for human AR and PR and improved our previous ER $\alpha$ and $E R \beta$ reporter gene assay yeasts by deleting the CWP1/CWP2 and/or PDR5/ PDR10 genes. The elimination of the CWPs Cwp1p/
A

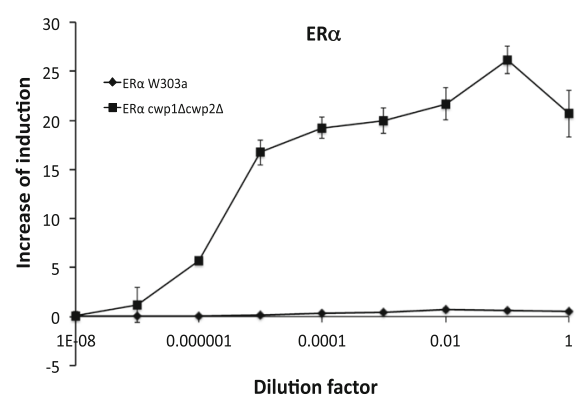

C

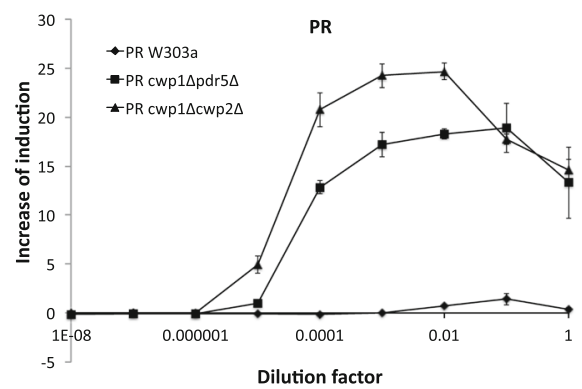

B

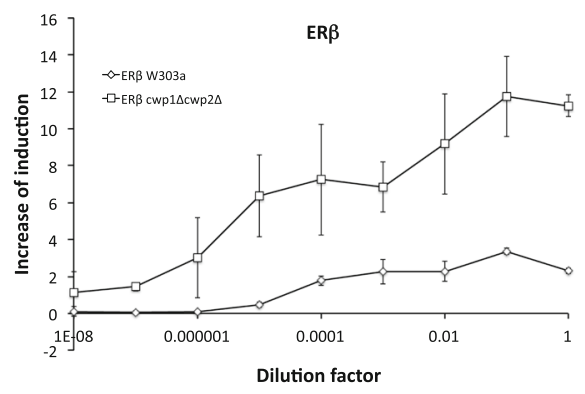

D

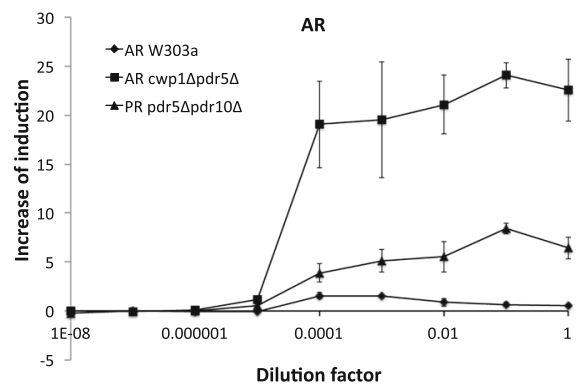

Fig. 8 Detection of synthetic sex hormone activities from oral tablets. Organic compounds were extracted from oral pharmaceutical tablets Lunabel $\|^{\oplus}$ and concentrated. Using serially diluted samples as ligands, yeast reporter gene assays were performed using yeasts expressing ERa and ERß (W303a and cwp 1 $\Delta c w p 2 \Delta$ ), PR (W303a, cwp 1 $\Delta p d r 5 \Delta$, and cwp 1 $\Delta c w p 2 \Delta$ ), and AR (W303a, cwp 1 $\Delta p d r 5 \Delta$, and pdr5 $\Delta p d r 10 \Delta)$ : ERa (A), ERß $(B), P R(C)$, and $A R(D)$. Data represent the mean $\pm S D$ of triplicate experiments 

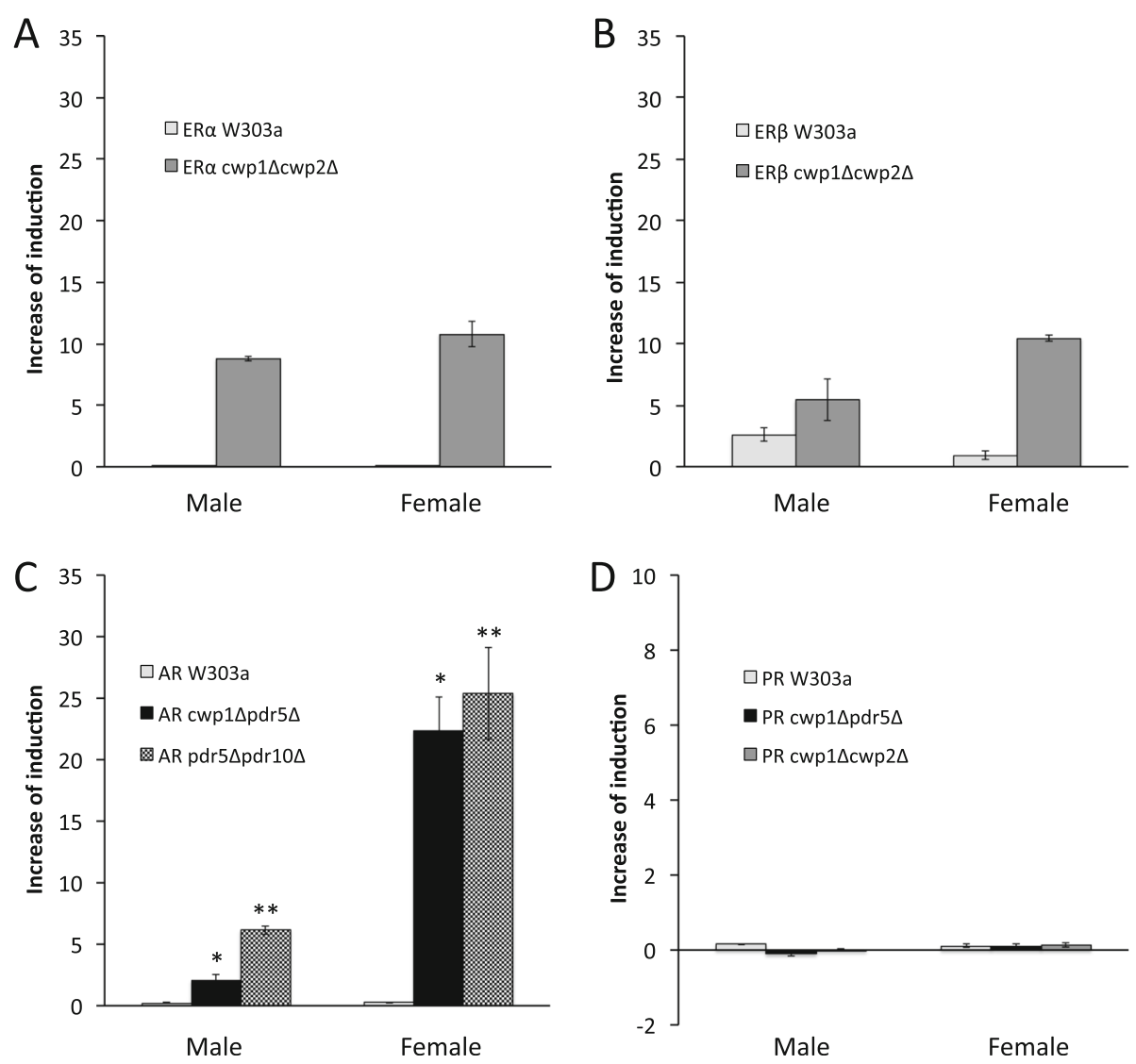

Fig. 9 Detection of sex hormone activities from human urine. Organic compounds were extracted and concentrated from urine provided by a male and a female. Samples were serially diluted and used in the reporter gene assay using the yeast strains expressing ERa and ER (W303a and cwp $1 \Delta c w p 2 \Delta$ ), PR (W303a, cwp 1 $\Delta p d r 5 \Delta$, and cwp 1 $\Delta c w p 2 \Delta$ ), and AR (W303a, cwp 1 $\Delta p d r 5 \Delta$, and pdr5 $\Delta p d r 10 \Delta)$ : ERa (A), ERß (B), AR (C), and PR (D). Graphs indicate reporter activity of urine samples with the concentration factor of 50. Data represent the mean \pm SD of triplicate experiments. Reporter activity was significantly different between male and female urine samples in AR-expressing mutant strains: ${ }^{*} C w p 1 \Delta p d r 5 \Delta(p<0.0005)$; ${ }^{* *} p d r 5 \Delta p d r 10 \Delta(p<0.001)$

Cwp2p and/or plasma membrane efflux pumps Pdr5p/ Pdr10p in host yeast cells markedly increased the sensitivities of sex steroid hormone receptors, as observed for corticosteroid receptors in our previous study [28].

The examination of a number of endogenous and synthetic ligands revealed that $\mathrm{EC}_{50}$ values and the minimum detection limit of the $c w p / p d r$ assay yeasts were lower than those of wild-type assay yeast. The only exception was the AR-expressing yeast strain, the sensitivity of which did not markedly differ from that of the wild-type strain (Fig. 1 Fig. 7, Table 1-3, and Table S-3S-6). Non-polar and hydrophobic steroid compounds may have very low permeability in the yeast cell membrane. To further improve AR-expressing yeast, the deletion of the ERG6 gene, which is involved in the synthesis of fungalspecific membrane lipid ergosterol, may effectively increase the permeability of the cell membrane [70, 71].

In the assay of ER $\alpha$ - and ER $\beta$-expressing $c w p / p d r$ mutant yeasts, ER $\alpha$ exhibited markedly stronger reporter activity than ER $\beta$ in response to both natural and synthetic estrogenic agonists (Fig. 1a-c, and Fig. 3). This result is consistent with previous findings showing that the transactivation activity of ER $\beta$ was weaker than ER $\alpha$ in most cell systems [72, 73], suggesting subtype-specific responses to the effects of estrogen [74-76].

In assays on cross-reactions of steroid hormones with their sex steroid hormone receptors, E1, E2, and PS induced strong AR-mediated reporter gene expression. Although the $\mathrm{EC}_{50}$ values of estrogens and $\mathrm{PS}$ in the $\mathrm{AR}$ reporter gene assay were markedly higher than those of TS and DHT (Table S-3), they induced strong transactivation activity of AR (Fig. 2a and c). In the assay of TS in ER $\beta$ and PR-expressing yeasts and CS in PR assay yeasts, ligand responses were weak (Fig. $2 b, d$, and f). These results correlated with the structural similarity of ligands and LBD among receptors [77-79]. The crossreactivity observed in the present study reflected the intrinsic potential of ligand-receptor interactions in vivo, which is often associated with the adverse side effects of pharmaceuticals with steroid hormone activity [62, 63, 
80]. Cross-reactivity also provides important information for predicting the constituents of sex steroid hormones in reporter gene assays of environmental test samples.

Several unique characteristics of ligand responses were identified in the present study. The ligand potencies of endogenous ligands E1 and E2 for ER $\alpha / E R \beta$ and TS and DHT for AR were similar in the yeast assays (Table 1), which is in contrast to previous findings: E2 is more potent ligand than E1 for ERs, and DHT is more potent than TS for AR, respectively, in mammalian cell-based reporter gene assays [26, 49, 81, 82]. In the mammalian cell reporter gene assay, Ral only exhibited partial agonist activity on ER $\alpha$, but induced reporter activity in both the ER $\alpha$ and ER $\beta$ assay yeasts, with stronger responses in ER $\beta$. The partial agonist potential of MPP was observed for both ER $\alpha$ and ER $\beta$ (Fig. 5e and f), which has not been reported previously [26]. The antagonism of Ral and MPP was not observed in yeasts, which may have been due to the markedly stronger ligand-independent $\beta$-gal activity of $E R \alpha$ and ER $\beta$-expressing yeasts (data not shown). We also identified an inverse agonist activity of ICI (Fig. $5 \mathrm{~g}$ ), as reported previously in vivo [56]. We detected the moderate inverse agonist activity of Tam on ER $\alpha$ and ER $\beta$ (Fig. 5h), suggesting its potential as an inverse agonist on ERs in vivo [57]. Other unique ligand responses in yeasts were observed in the assay of PR and AR against progestins (Fig. 7). Previous studies reported that progestins later than the third drug developmental generation exhibited stronger progestogenic activities and weaker androgenic activities than the previous generations in vivo $[62,63$, 83]; however, the sensitivity of PR-expressing assay yeast against DSG, DNG, and DRSP was markedly lower than those of the earlier generations (Fig. 7). The physiological activities of ligands in vivo may be affected by the metabolism of ligands as well as the expression and selectivity of transcriptional coactivators [84-86]. Some ligand substances may be more stable in yeast cells than in mammalian cells due to the lack of metabolic pathways of the ligands, and, thus, substance-receptor interaction potentials may be directly reflected in the yeast reporter gene assay.

Our newly established sex hormone receptor ligand assay yeasts were validated using pharmaceutical tablets and human urine. Lunabell ${ }^{\bullet}$ contains the synthetic estrogen EE2 and first generation progestin NET. $c w p / p d r$ mutant assay yeasts effectively detected ligand activity contained in the tablets (Fig. 8). Figure 3a and Fig. 7c and $\mathrm{d}$ showed that the mutant ER $\alpha$ and ER $\beta$ assay strains responded to EE2, while the mutant PR and AR assay strains responded to NET. The mutant AR assay strains also responded to EE2 (Fig. 4f). In the assay of urine, $c w p / p d r$ mutant assay yeasts expressing ER $\alpha$ and ER $\beta$ detected hormone activity excreted into urine from both male and female (Fig. 9a and b). A small amount of estrogens are also produced in males through the conversion of androgens [87]. In contrast, even $c w p / p d r$ mutant PR yeasts did not detect ligand activity (Fig. 9d). This result suggested that the primary ligand PS or cross-reacting ligand androgens did not exist as active hormone forms in urine [88, 89]. The AR-expressing $c w p / p d r$ mutant strains strongly detected ligand activity in female sample (Fig. 9c); however, active androgens did not appear to be abundant in female urine. As described above, estrogens E1 and E2 strongly crossreacted with $\mathrm{AR}$ in the $c w p / p d r$ mutant strains (Fig. 2a and g). The stronger reporter activity observed in mutant AR-expressing yeasts was due to active estrogens contained in female urine.

\section{Conclusion}

In the present study, we newly constructed highly sensitive reporter gene assay yeasts for the sex steroid hormone receptors ER $\alpha, E R \beta$, AR, and PR. Yeast reporter gene assay systems for all six steroid hormone receptors are now available, including previously established GR and MR assay yeasts [28]. By arraying these assay yeasts in a 96-well microtiter plate, environmental endocrine disrupters with steroid hormone activity will be qualitatively and simultaneously detectable by simple and easy procedures. The yeast-based reporter gene assay will be valuable as a primary screening tool to detect and evaluate steroid hormone activities in various test samples. Our assay system will strongly support the detection of agonists, antagonists, and inverse agonists of steroid hormone receptors in the field of novel drug discovery and assessments of environmental pollutants.

\section{Supplementary information}

Supplementary information accompanies this paper at https://doi.org/10. 1186/s41021-020-00159-x.

Additional file 1: Table S-1. S. cerevisiae strains. Table S-2. Primer sequences. Table S-3. $\mathrm{EC}_{50}$ values $(\mu \mathrm{M})$ of various steroid hormones in yeast strains expressing human sex hormone receptors. Table S-4. Comparison of responses of yeast strains expressing human sex hormone receptors against known antagonist ligands. Table S-5. Partial agonist activity of known antagonist ligands in yeast strains expressing human sex hormone receptors. Table S-6. Anti-AR activity of the fourth generation of progestins in yeast.

Additional file 2: Figure S1. Dose-dependent responses to sex steroid hormones in ER, ER, PR, and AR in wild-type W303a and mutants. The reporter assay yeast strains expressing human ER (A), ER (B), PR (C), and AR (D) were established in wild-type yeast W303a and deletion mutants for cell wall mannoproteins (CWP1, CWP2) and/or plasma membrane efflux pumps (PDR5, PDR10). The yeast strains were exposed to E2 (A and B), PS (C), and TS (D), and the ligand-dependent induction of -galactosidase activity was measured. Figure S2. Dose-dependent responses of ER- and ER-expressing yeast strains exposed to E2 in medium containing increased amounts of glucose. ER- and ER-expressing wild-type W303a and cwp1cwp2strains were exposed to E2 in medium containing $1.2 \%$ glucose and $0.8 \%$ galactose, which was applied for the assay of synthetic estrogens shown in Fig. 3, in order to minimize ligand-independent reporter induction. 


\section{Abbreviations}

17a-MAS: 17a-Methylandrostan-17ß-ol-3-one; 17a-MTS: 17a-

Methyltestosterone; $17 \beta-H$ : 17ß-Hydroxy-17-methylandrosta-1,4-dien-3-one; AR: Androgen receptor; AS: Aldosterone; CS: Corticosterone; CWP: Cell wall mannoprotein; DES: Diethylstilbestrol; DHT: 5a-Dihydrotestosterone; DMSO: Dimethyl sulfoxide; DNG: Dienogest; DPN: Diarylpropionitrile; DRSP: Drospirenone; DSG: Desogestrel; DTT: Dithiothreitol; E1: Estrone; E2: 17ß-Estradiol; E3: Estriol; EE2: Ethinyl estradiol; ER: Estrogen receptor; ERE: Estrogen response element; Flu: Flutamide; GR: Glucocorticoid receptor; GRE: Glucocorticoid response element; GTD: Gestodene; HC: Hydrocortisone; ICI: ICI 182, 780; LNG: Levonorgestrel; Mif: Mifepristone;

MPA: Medroxyprogesterone 17-acetate; MPP: Methyl-piperidino-pyrazole dihydrochloride hydrate; MR: Mineralocorticoid receptor; NET: 19norethindrone; NR: Nuclear receptor; ONPG: o-nitrophenyl- $\beta$-Dgalactopyranoside; PDR: Pleiotropic drug resistance; PPT: Propyl pyrazole triol; PR: Progesterone receptor; PS: Progesterone; Ral: Raloxifen; Spi: Spironolactone; STA: Stanozolol; Tam: Tamoxifen; TBA: Trenbolone acetate; Zer: Zeranole

\section{Acknowledgements}

The authors thank Dr. Ryoichi Yamaji (Osaka Prefecture University, Japan) for providing a plasmid.

\section{Authors' contributions}

S. I.-H. and K. S. designed the study. K. S., K. O., and S. E. constructed the plasmids and established reporter gene assays for AR and PR. S. I.-H., M. M., S. $\mathrm{N}$., and T. N. contributed to improvements in reporter gene assay yeasts, and validated them with various ligands. S. I.-H. conducted data analyses and wrote the manuscript. M. K. contributed to the preparation of essential materials and resources from the grants. T. Y. organized the research project and arranged necessary resources from the grants. The author(s) read and approved the final manuscript.

\section{Funding}

This work was supported by the following research grants. The Industrial Technology Research Grant Program from the New Energy and Industrial Technology Development Organization (NEDO) (\#05A21501a) in 2005-2007 (M. K.), The Science and Technology Incubation Program in Advanced Regions from The Japan Science and Technology Agency (JST) (\#OSAKA H23-1) in 2009-2011 (T. Y.), Grants-in-Aid for Scientific Research from The Japan Society for the Promotion of Science (JSPS) (KAKENHI \#18651028) in 2006-2008 (T.Y.), and a Basic Research Grant from Osaka Prefecture University in 2011-2019 (T. Y., M. K.).

\section{Availability of data and materials} Not applicable.

\section{Ethics approval and consent to participate}

Human urine was supplied by voluntary students with informed consent, and the use of urine in the present study was approved by the Research Ethics Committee of Osaka Prefecture University.

\section{Consent for publication}

Not applicable.

\section{Competing interests}

The authors declare that they have no competing interests.

\section{Author details}

'Department of Biological Sciences, Graduate School of Science, Osaka Prefecture University, 1-2 Gakuen-cho, Naka-ku, Sakai, Osaka 599-8570, Japan. 2Present address: Department of Applied Biosciences, Graduate School of Life Sciences, Toyo University, 1-1-1 Izumino, Itakura-machi, Ora-gun, Gunma 374-0193, Japan.

Received: 19 March 2020 Accepted: 16 May 2020 Published online: 27 May 2020

\section{References}

1. Mooradian AD, Morley JE, Korenman SG. Biological actions of androgens. Endocr Rev. 1987;8:1-28.
2. Ciocca DR, Vargas Roig LM. Estrogen receptors in human nontarget tissues: biological and clinical implications. Endocr Rev. 1995;16:35-62.

3. Graham JD, Clarke CL. Physiological action of progesterone in target tissues. Endocr Rev. 1997;18:502-19.

4. Turgeon JL, Carr MC, Maki PM, Mendelsohn ME, Wise PM. Complex actions of sex steroids in adipose Ttissue, the cardiovascular system, and brain: linsights from bBasic science and clinical studies. Endocr Rev. 2006;27:575-605.

5. Mangelsdorf DJ, Thummel C, Beato M, Herrlich P, Schutz G, Umesono K, et al. The nuclear receptor superfamily: the second decade. Cell. 1995;83:835-9.

6. Klein-Hitpass L, Ryffel GU, Heitlinger E, Cato ACB. A 13 bp palindrome is a functional estrogen responsive element and interacts specifically with estrogen receptor. Nucleic Acids Res. 1988;16:647-63.

7. Peale FV, Ludwig LB, Zain S, Hilf R, Bambara RA. Properties of a high-affinity DNA binding site for estrogen receptor. Proc Natl Acad Sci U S A. 1988;85:1038.

8. Cato AC, Skroch P, Weinmann J, Butkeraitis P, Ponta H. DNA sequences outside the receptor-binding sites differently modulate the responsiveness of the mouse mammary tumour virus promoter to various steroid hormones. EMBO J. 1988;7:1403-10.

9. Ham J, Thomson A, Needham M, Webb P, Parker M. Characterization of response elements for androgens, glucocorticoids and progestins in mouse mammary tumour virus. Nucleic Acids Res. 1988;16:5263-76.

10. Jenster G. Coactivators and corepressors as mediators of nuclear receptor function: an update. Mol Cell Endocrinol. 1998;143:1-7.

11. Xu L, Glass CK, Rosenfeld MG. Coactivator and corepressor complexes in nuclear receptor function. Curr Opin Genet Dev. 1999;9:140-7.

12. Lee JW, Lee YC, Na SY, Jung DJ, Lee SK. Transcriptional coregulators of the nuclear receptor superfamily: coactivators and corepressors. Cell Mol Life Sci. 2001;58:289-97.

13. Forbes GB. The effect of anabolic steroids on lean body mass: the dose response curve. Metabolism. 1985;34:571-3.

14. Griggs RC, Kingston W, Jozefowicz RF, Herr BE, Forbes G, Halliday D. Effect of testosterone on muscle mass and muscle protein synthesis. J Appl Physiol (1985). 1989; 66:498-503.

15. Guerriero G. Vertebrate sex steroid receptors: evolution, ligands, and neurodistribution. Ann N Y Acad Sci. 2009;1163:154-68.

16. Nilsson S, Mäkelä S, Treuter E, Tujague M, Thomsen J, Andersson G, et al. Mechanisms of estrogen action. Physiol Rev. 2001;81:1535-65.

17. Deroo BJ, Korach KS. Estrogen receptors and human disease. J Clin Invest. 2006;116:561-70.

18. Henderson BE, Feigelson HS. Hormonal carcinogenesis. Carcinogenesis. 2000:21:427-33.

19. Prins GS, Korach KS. The role of estrogens and estrogen receptors in normal prostate growth and disease. Steroids. 2008;73:233-44.

20. Journal of the National Cancer InstituteFarhat GN, Cummings SR, Chlebowski RT, Parimi N, Cauley JA, Rohan TE, et al. Sex hormone levels and risks of estrogen receptor-negative and estrogen receptor-positive breast cancers. J Natl Cancer Inst. 2011; 103:562-70.

21. Greendale GA, Edelstein S, Barrett-Connor E. Endogenous sex steroids and bone mineral density in older women and men: the rancho Bernardo study. J Bone Miner Res. 1997:12:1833-43.

22. Crandall CJ, Guan M, Laughlin GA, Ursin GA, Stanczyk FZ, Ingles SA, et al. Increases in serum estrone sulfate level are associated with increased mammographic density during menopausal hormone therapy. Cancer Epidemiol Biomark Prev. 2008;17:1674.

23. van der Linden SC, Heringa MB, Man H-Y, Sonneveld E, Puijker LM, Brouwer $A$, et al. Detection of multiple hormonal activities in wastewater effluents and surface water, using a panel of steroid receptor CALUX bioassays. Environ Sci Technol. 2008:42:5814-20.

24. Streck G. Chemical and biological analysis of estrogenic, progestagenic and androgenic steroids in the environment. Trends Anal Chem. 2009;28:635-52.

25. Görög S. Advances in the analysis of steroid hormone drugs in pharmaceuticals and environmental samples (2004-2010). J Pharm Biomed Anal. 2011;55:728-43.

26. Wilkinson JM, Hayes S, Thompson D, Whitney P, Bi K. Compound profiling using a panel of steroid hormone receptor cell-based assays. J Biomol Screen. 2008;13:755-65.

27. Chu WL, Shiizaki K, Kawanishi M, Kondo M, Yagi T. Validation of a new yeast-based reporter assay consisting of human estrogen receptors $\alpha / \beta$ and 
coactivator SRC-1: application for detection of estrogenic activity in environmental samples. Environ Toxicol. 2009;24:513-21.

28. Ito-Harashima S, Shiizaki K, Kawanishi M, Kakiuchi K, Onishi K, Yamaji R, et al. Construction of sensitive reporter assay yeasts for comprehensive detection of ligand activities of human corticosteroid receptors through inactivation of CWP and PDR genes. J Pharmacol Toxicol Methods. 2015;74:41-52.

29. Sanseverino J, Eldridge ML, Layton AC, Easter JP, Yarbrough J, Schultz TW, et al. Screening of potentially hormonally active chemicals using bioluminescent yeast bioreporters. Toxicol Sci. 2009;107:122-34.

30. Kolle SN, Kamp HG, Huener HA, Knickel J, Verlohner A, Woitkowiak C, et al. In house validation of recombinant yeast estrogen and androgen receptor agonist and antagonist screening assays. Toxicol in Vitro. 2010;24:2030-40.

31. Sonneveld E, Jansen HJ, Riteco JA, Brouwer A, van der Burg B. Development of androgen- and estrogen-responsive bioassays, members of a panel of human cell line-based highly selective steroid-responsive bioassays. Toxicol Sci. 2005;83:136-48.

32. Kralli A, Bohen SP, Yamamoto KR. LEM1, an ATP-binding-cassette transporter selectively modulates the biological potency of steroid hormones. Proc Natl Acad Sci U S A. 1995;92:4701-5.

33. Zhang $M$, Liang $Y$, Zhang $X, X u Y$, Dai $H$, Xiao W. Deletion of yeast CWP genes enhances cell permeability to genotoxic agents. Toxicol Sci. 2008;103:68-76.

34. Zhang M, Hanna M, Li J, Butcher S, Dai H, Xiao W. Creation of a hyperpermeable yeast strain to genotoxic agents through combined inactivation of PDR and CWP genes. Toxicol Sci. 2010;113:401-11.

35. Kawanishi M, Mori K, Yamada R, Ito-Harashima S, Yagi T. Improvement of reporter gene assay for highly sensitive dioxin detection using protoplastic yeast with inactivation of CWP and PDR genes. Environ Sci Pollut Res. 2020; 27:9227-35.

36. Klis FM, Boorsma A, De Groot PW. Cell wall construction in Saccharomyces cerevisiae. Yeast. 2006;23:185-202.

37. Klis FM, Mol P, Hellingwerf $K$, Brul S. Dynamics of cell wall structure in Saccharomyces cerevisiae. FEMS Microbiol Rev. 2002;26:239-56.

38. van der Vaart JM, Caro LH, Chapman JW, Klis FM, Verrips CT. Identification of three mannoproteins in the cell wall of Saccharomyces cerevisiae. J Bacteriol. 1995; 177:3104-10.

39. Burke D, Dawson D, Stearns T. Methods in yeast genetics-a laboratory course manual, cold Spring Harbor (2000 edition). Cold Spring Harbor Laboratory Press: Cold Spring Harbor; 2000.

40. Harada N, Yasunaga R, Higashimura Y, Yamaji R, Fujimoto K, Moss J, et al. Glyceraldehyde-3-phosphate dehydrogenase enhances transcriptional activity of androgen receptor in prostate cancer cells. J Biol Chem. 2007;282: 22651-61.

41. Shiizaki K, Asai S, Ebata S, Kawanishi M, Yagi T. Establishment of yeast reporter assay systems to detect ligands of thyroid hormone receptors a and $\beta$. Toxicol in Vitro. 2010;24:638-44.

42. Gietz RD, Schiestl RH, Willems AR, Woods RA. Studies on the transformation of intact yeast cells by the LiAc/SS- DNA/PEG procedure. Yeast. 1995;11: 355-60.

43. Gietz RD, Sugino A. New yeast-Escherichia coli shuttle vectors constructed with in vitro mutagenized yeast genes lacking six-base pair restriction sites. Gene. 1988;74:527-34.

44. Goa KL, Warner GT, Easthope SE. Transdermal ethinylestradiol/ norelgestromin. Treat Endocrinol. 2003:2:191-206.

45. Warren MP. A comparative review of the risks and benefits of hormone replacement therapy regimens. Am J Obstet Gynecol. 2004;190:1141-67.

46. Marselos M, Tomatis L. Diethylstilboestrol: I, pharmacology, toxicology and carcinogenicity in humans. Eur J Cancer. 1992;28:1182-9.

47. Marselos M, Tomatis L. Diethylstilboestrol: II, pharmacology, toxicology and carcinogenicity in experimental animals. Eur J Cancer. 1993;29:149-55.

48. Harrington WR, Sheng S, Barnett DH, Petz LN, Katzenellenbogen JA, Katzenellenbogen BS. Activities of estrogen receptor alpha- and betaselective ligands at diverse estrogen responsive gene sites mediating transactivation or transrepression. Mol Cell Endocrinol. 2003;206:13-22.

49. Escande A, Pillon A, Servant N, Cravedi J-P, Larrea F, Muhn P, et al. Evaluation of ligand selectivity using reporter cell lines stably expressing estrogen receptor alpha or beta. Biochem Pharmacol. 2006;71:1459-69.

50. Cosman F, Lindsay R. Selective estrogen receptor modulators: clinical spectrum. Endocr Rev. 1999;20:418-34.

51. Cellotti F, Cesi PN. Anabolic steroids: a review of their effects on the muscles, of their possible mechanisms of action and of their use in athletics. J Steroid Biochem Mol Biol. 1992;43:469-77.
52. Kicman AT. Pharmacology of anabolic steroids. Br J Pharmacol. 2009;154 502-21.

53. Thiblin I, Petersson A. Pharmacoepidemiology of anabolic androgenic steroids: a review. Fundam Clin Pharmacol. 2004;19:27-44.

54. Basaria S, Wahlstrom JT, Dobs AS. Anabolic-androgenic steroid therapy in the treatment of chronic diseases. J Clin Endocrinol Metab. 2001;86:5108-17.

55. Shahidi NT. A review of the chemistry, biological action, and clinical applications of anabolic-androgenic steroids. Clin Ther. 2001;23:1355-90.

56. Movérare-Skrtic S, Börjesson AE, Farman HH, Sjögren K, Windahl SH, Lagerquist MK, et al. The estrogen receptor antagonist ICI 182,780 can act both as an agonist and an inverse agonist when estrogen receptor a AF-2 is modified. Proc Natl Acad Sci U S A. 2014;111:1180.

57. Prather PL, FrancisDevaraj F, Dates CR, Greer AK, Bratton SM, Ford BM, et al. CB1 and CB2 receptors are novel molecular targets for Tamoxifen and $4 \mathrm{OH}$ Tamoxifen. Biochem Biophys Res Commun. 2013:441:339-43.

58. de Gasparo M, Joss U, Ramjoue HP, Whitebread SE, Haenni H, Schenkel L, et al. Three new epoxy-spirolactone derivatives: characterization in vivo and in vitro. J Pharmacol Exp Ther. 1987;240:650-6.

59. Poyet $P$, Labrie F. Comparison of the antiandrogenic/androgenic activities of flutamide, cyproterone acetate and megestrol acetate. Mol Cell Endocrinol. 1985:42:283-8.

60. Molina-Molina JM, Real M, Jimenez-Diaz I, Belhassen H, Hedhili A, Torne P, et al. Assessment of estrogenic and anti-androgenic activities of the mycotoxin zearalenone and its metabolites using in vitro receptor-specific bioassays. Food Chem Toxicol. 2014;74:233-9.

61. La Rosa JC. The varying effects of progestins on lipid levels and cardiovascular disease. Am J Obstet Gynecol. 1988;158:1621-9.

62. Madauss KP, Stewart EL, Williams SP. The evolution of progesterone receptor ligands. Med Res Rev. 2007;27:374-400.

63. Sitruk-Ware R. Pharmacological profile of progestins. Maturitas. 2008;61:151-7.

64. Ito-Harashima S, Yagi T. Unique molecular mechanisms for maintenance and alteration of genetic information in the budding yeast Saccharomyces cerevisiae. Genes Environ. 2017;39:28.

65. Matsui S, Ito-Harashima S, Sugimoto Y, Takada E, Shiizaki K, Kawanishi M, et al. Development of yeast reporter assays for the enhanced detection of environmental ligands of thyroid hormone receptors $\alpha$ and $\beta$ from Xenopus tropicalis. Toxicol in Vitro. 2016;37:15-24.

66. Ito-Harashima S, Matsuura M, Kawanishi M, Nakagawa Y, Yagi T. New reporter gene assays for detecting natural and synthetic molting hormone agonists using yeasts expressing ecdysone receptors of various insects. FEBS Open Bio. 2017;7:995-1008

67. Kawanishi M, Sakamoto M, Ito A, Kishi K, Yagi T. Construction of reporter yeasts for mouse aryl hydrocarbon receptor ligand activity. Mutat Res. 2003; 540:99-105.

68. Shiizaki K, Yoshikawa T, Takada E, Hirose S, Ito-Harashima S, Kawanishi M, et al. Development of yeast reporter assay for screening specific ligands of retinoic acid and retinoid $X$ receptor subtypes. J Pharmacol Toxicol Methods. 2014;69:245-52.

69. Kawanishi M, Sakamoto M, Shimohara C, Yagi T. Establishment of reporter yeasts for Guinea pig and Syrian hamster aryl hydrocarbon receptor ligand activity. Genes Environ. 2006;28:167-72.

70. Sitcheran R, Emter R, Kralli A, Yamamoto KR. A genetic analysis of glucocorticoid receptor signaling. Identification and characterization of ligand-effect modulators in Saccharomyces cerevisiae. Genetics. 2000;156: 963-72

71. Emter R, Heese-Peck A, Kralli A. ERG6 and PDR5 regulate small lipophilic drug accumulation in yeast cells via distinct mechanisms. FEBS Lett. 2002; 521:57-61.

72. Mosselman S, Polman J, Dijkema R. ER beta: identification and characterization of a novel human estrogen receptor. FEBS Lett. 1996;392: 49-53.

73. Ogawa S, Eng V, Taylor J, Lubahn DB, Korach KS, Pfaff DW. Roles of estrogen receptor-a gene expression in reproduction-related behaviors in female mice. Endocrinology. 1998;139:5070-81.

74. Pettersson K, Gustafsson J-Ö. Role of estrogen receptor beta in estrogen action. Annu Rev Physiol. 2001:63:165-92.

75. Ali S, Coombes RC. Estrogen receptor alpha in human breast cancer: occurrence and significance. J Mammary Gland Biol Neoplasia. 2000;5:271-81.

76. Chu S, Mamers P, Burger HG, Fuller PJ. Estrogen receptor isoform gene expression in ovarian stromal and epithelial tumors. J Clin Endocrinol Metab. 2000;85:1200-5. 
77. Arriza JL, Weinberger C, Cerelli G, Glaser TM, Handelin BL, Housman DE, et al. Cloning of human mineralocorticoid receptor complementary DNA: structural and functional kinship with the glucocorticoid receptor. Science. 1987;237:268-75

78. Berger TS, Parandoosh Z, Perry BW, Stein RB. Interaction of glucocorticoid analogues with the human glucocorticoid receptor. I Steroid Biochem Mol Biol. 1992;41:733-8.

79. Bovee TF, Helsdingen RJ, Hamers AR, Brouwer BA, Nielen MW. Recombinant cell bioassays for the detection of (gluco) corticosteroids and endocrinedisrupting potencies of several environmental PCB contaminants. Anal Bioanal Chem. 2011:401:873-82.

80. Garabedian MJ, Yamamoto KR. Genetic dissection of the signaling domain of a mammalian steroid receptor in yeast. Mol Biol Cell. 1992;3:1245-57.

81. Grino PB, Griffin JE, Wilson JD. Testosterone at high concentrations interacts with the human androgen receptor similarly to dihydrotestosterone. Endocrinology. 1990;126:1165-72.

82. Deslypere JP, Young M, Wilson JD, McPhaul MJ. Testosterone and 5adihydrotestosterone interact differently with the androgen receptor to enhance transcription of the MMTV-CAT reporter gene. Mol Cell Endocrinol. 1992;88:15-22

83. Kloosterboer HJ, Vonk-Noordegraaf CA, Turpijn EW. Selectivity in progesterone and androgen receptor binding of progestagens used in oral contraceptives. Contraception. 1988;38:325-32.

84. Heinlein CA, Chang C. Androgen receptor (AR) coregulators: an overview. Endocr Rev. 2002;23:175-200.

85. Edwards CR, Stewart PM, Burt D, Brett L, McIntyre MA, Sutanto WS, et al. Localisation of 11 beta-hydroxysteroid dehydrogenase--tissue specific protector of the mineralocorticoid receptor. Lancet. 1988;2:986-9.

86. Lim-Tio SS, Keightley MC, Fuller PJ. Determinants of specificity of transactivation by the mineralocorticoid or glucocorticoid receptor. Endocrinology. 1997;138:2537-43.

87. Longcope C, Kato T, Horton R. Conversion of blood androgens to estrogens in normal adult men and women. J Clin Invest. 1969;48:2191-201.

88. Davis ME, Plotz EJ, LeRoy GV, Gould RG, Werbin H. Hormones in human reproduction: part I: metabolism of progesterone. Am J Obstet Gynecol. 1956;72:740-55.

89. Miller AM, Dorfman RI, Miller MAX. Metabolism of the steroid hormones: metabolism of dehydroisoandrosterone. Endocrinology. 1950;46:105-10.

\section{Publisher's Note}

Springer Nature remains neutral with regard to jurisdictional claims in published maps and institutional affiliations.

Ready to submit your research? Choose BMC and benefit from:

- fast, convenient online submission

- thorough peer review by experienced researchers in your field

- rapid publication on acceptance

- support for research data, including large and complex data types

- gold Open Access which fosters wider collaboration and increased citations

- maximum visibility for your research: over $100 \mathrm{M}$ website views per year

At $\mathrm{BMC}$, research is always in progress.

Learn more biomedcentral.com/submissions 